\title{
Estrogen receptor alpha-36 (ER- $\alpha 36)$ : a new player in human breast cancer
}

Zhao-Yi Wang* and Li Yin,

Department of Medical Microbiology \& Immunology, Creighton University Medical School, 2500 California Plaza, Omaha, NE 68178.

*Correspondence to Zhao-Yi Wang, Criss III, Room 352, Creighton University Medical School, 2500 California Plaza, Omaha, NE 68178. Fax: (402) 280-3543. E. Mail: zywang@creighton.edu

Short Title: ER- $\alpha 36$ in breast cancer.

Key Words: ER- $\alpha 36$, rapid estrogen signaling, ER-positive and -negative breast cancer, breast cancer stem/progenitor cells, antiestrogen resistance. 


\begin{abstract}
Prevailing wisdom is that estrogen receptor (ER)- $\alpha$ mediated genomic estrogen signaling is responsible for estrogen-stimulated cell proliferation and development of ER-positive breast cancer. However, accumulating evidence indicates that another estrogen signaling pathway, nongenomic or rapid estrogen signaling, also plays an important role in mitogenic estrogen signaling. Previously, our laboratory cloned a $36 \mathrm{kDa}$ variant of ER- $\alpha$, ER- $\alpha 36$, and found that ER- $\alpha 36$ is mainly expressed in the cytoplasm and at the plasma membrane. ER- $\alpha 36$ mediates rapid estrogen signaling and inhibits genomic estrogen signaling. In this review, we review and update the biological function of ER- $\alpha 36$ in ER-positive and -negative breast cancer, breast cancer stem/progenitor cells and tamoxifen resistance, potential interaction and cross-talk of ER$\alpha 36$ with other ERs and growth factor receptors, and intracellular pathways of ER- $\alpha 36$-mediated rapid estrogen signaling. The potential function and underling mechanism of ER- $\alpha$ in development of ER-positive breast cancer will also be discussed.
\end{abstract}




\section{Introduction}

Estrogen signaling is essential in the initiation and development of human breast cancer. In the past several decades, extensive efforts have been dedicated to understand the underlying mechanisms of this important signaling pathway in human breast cancer, which have facilitated the development of anti-estrogen therapy, the first targeted therapy for human cancer.

It has been well documented that the diverse activities of estrogens and anti-estrogens are mediated by specific receptors designated as estrogen receptors (ERs) (Nilsson et al., 2001). Currently, there are two identified ERs, ER- $\alpha$ and ER- $\beta$, both of which are ligand-activated transcription factors that stimulate target gene transcription (Nilsson et al., 2001). Compelling evidence indicates that estrogens, especially $17 \beta$-estradiol (E2 $\beta)$, up-regulate the expression and function of c-Myc and cyclinD1, activate cyclin E-Cdk2 complexes and promotes cell cycle progression from G1 to S phase in mammary epithelial cells (Rochefort et al., 1995). Thus, stimulation of target gene expression by ERs in response to estrogens is prevailingly thought to be responsible for estrogen-stimulated mammary carcinoma initiation and progression.

Despite the clarity with which ERs have been shown to act as ligand-dependent transcription factors, it became apparent now that not all of the activities mediated by ERs are accomplished through a direct effect on gene transcription. Another signaling pathway (also known as a non-classic, non-genomic, extra-nuclear, rapid or membrane-initiated signaling pathway) exists that involves cytoplasmic signaling proteins, growth factor receptors and other membrane-initiated signaling pathways (Segars et al., 2002; Driggers et al., 2002; Kelly and Levin, 2001). Several intracellular signaling pathways have been shown cross-talking with the membrane-initiated estrogen signaling: the adenylate cyclase pathway, the phospholipase C pathway, the G-protein-coupled receptor-activated pathways, the PI3K/AKT and the MAPK pathways().

The identity of the membrane-based ER(s) that mediates rapid estrogen effects has been center for extensive research. ER- $\beta$ and two forms of ER- $\alpha$, full-length (66-kDa) and short form $(46-\mathrm{kDa})$ have been found on or near the plasma membrane and mediates membrane-initiated estrogen signaling (Razandi et al., 1999; Kelly and Levin, 2001; Li et al 2003). In addition, there is also evidence indicating that GPR30, an orphan G-protein-coupled-receptor, mediates the rapid, non-genomic responses to estrogens (Prossnitz and Barton 2011). In 2005, our laboratory identified and cloned a novel variant of ER- $\alpha$ that has a molecular weight of 36-kDa and thus we have termed it ER- $\alpha 36$. This ER- $\alpha$ variant differs from the original $66 \mathrm{kDa}$ ER- $\alpha$ (ER- $\alpha 66)$, lacking both transcriptional activation domains (AF-1 and AF-2) but retaining the DNA-binding domain and partial dimerization and ligand-binding domains (Wang et al., 2005; Wang et al., 2006). ER- $\alpha 36$ is predominantly expressed outside of the cell nucleus and at the plasma membrane of both ER-positive and -negative breast cancer cells, mediates rapid estrogen and anti-estrogen signaling such as activation of the MAPK/ERK and PI3K/AKT signaling pathways and stimulation of cell proliferation (Wang et al., 2006; Lin et al., 2010). Thus, ER- $\alpha 36$ is a novel membrane associated ER that mediates rapid estrogen and anti-estrogen signaling in both ER-positive and -negative breast cancer cells.

In this review, we highlight the historical understanding of the rapid estrogen signaling and its role in cell survival and proliferation, and specifically illustrate the biological function and the possible underlying mechanisms of ER- $\alpha 36$ in rapid estrogen signaling of both ERpositive and -negative breast cancer cells.

\section{Actions of estrogens}


Estrogen signaling is pivotal in the establishment and maintenance of reproductive function in men and women. Inappropriate estrogen signaling is involved in osteoporosis, atherosclerosis and Alzheimer's disease and is essential in the initiation and development of neoplasia in breast and endometrial cancers (Nilsson et al., 2001). Hence, extensive research has been conducted to understand the molecular mechanisms by which estrogen signaling functions. Currently two signaling pathways, genomic and non-genomic pathways, have been demonstrated.

\subsection{Genomic estrogen signaling}

It is well known that the physiological and pathological functions of estrogens are mediated by specific receptors designated as estrogen receptors (ERs). In 1986, the cloning of the ER was first reported (Green et al., 1986; Greene et al., 1986). Until 1996, it was assumed that there was only one ER responsible for all of the physiological and pharmacological effects of natural and synthetic estrogens and anti-estrogens. However, in 1996, a second ER was cloned (Kuiper et al., 1996). Currently, the first ER discovered is referred to as ER- $\alpha$, while the second is called ER- $\beta$.

ER- $\alpha$ and ER- $\beta$ share a common structural architecture (Reviewed by Kong et al., 2003; Zheng et al., 2003). Both are composed of three independent but interacting functional domains: the N-terminal A/B domain, the $\mathrm{C}$ or DNA-binding domain, and the D/E/F or ligand-binding domain. The N-terminal domain of ERs encodes a ligand-independent activation function (AF1), a region involved in interaction with co-activators, and transcriptional activation of target genes. The DNA-binding domain or $\mathrm{C}$ domain contains a two zinc-finger structure, which is involved in receptor dimerization and binding to specific DNA sequences. The $\mathrm{C}$-terminal E/F domain is a ligand-binding domain that mediates ligand binding, receptor dimerization, nuclear translocation, and a ligand-dependent transactivation function (AF-2). The relative contributions that both AF-1 and AF-2 exert on transcriptional control vary in a cell-specific and DNA promoter-specific manner (Berry et al., 1990; Tzukerman et al., 1994).

ERs are members of the nuclear receptor superfamily that control various physiological processes. It was thought that this control occurs through the regulation of gene transcription (Reviewed by Katzenellenbogen \& Katzenellenbogen, 2000; McDonnell \& Norris, 2002). ER utilizes multiple mechanisms to either activate or repress transcription of its target genes. These mechanisms include: (a) direct interaction of the ligand-occupied receptor with DNA at a consensus estrogen response elements (ERE, GGTCAnnnTGACC) followed by recruitment of transcriptional co-regulators or mediator complexes (Reviewed by Klinge, 2001), (b) interaction of the ligand-occupied ER with other transcription factors such as AP-1 (Kushner at al., 2000), Sp1 (Safe, 2001) or NF-kB (McKay \& Cidlowski, 1999), (c) indirect modulation of gene transcription via sequestration of general/common transcriptional components (Harnish et al., 2000; Speir et al., 2000). (d) direct phosphorylation and activation of unliganded receptor by the MAPK/ERK pathway (Kato et al., 1995; Bunone et al., 1996). In addition, the ability of an ER to regulate transcription through these mechanisms appears to be cell-type specific, perhaps due to differences in the complement of transcriptional co-regulatory factors available in each cell type (Cerillo et al., 1998; Evans et al., 2001; Maret et al., 1999). Also, transcriptional regulation is dependent upon the nature of the ligand, with various natural and synthetic selective estrogen receptor modulators (SERM) acting as either ER agonists or antagonists through these various mechanisms (Shang \& Brown, 2002; Katzenellenbogen \& Katzenellenbogen, 2002; Margeat et al., 2003). 


\subsection{Non-genomic estrogen signaling}

It become clear now that estrogens elicit two signaling pathways; the first requires hours to days to result in transcriptional changes of target genes and is known as genomic, classic or nuclear signaling pathway while the second occurs in seconds to minutes after estrogen treatment and usually initiates at the plasma membrane. Thus, the second signaling pathway is also known as a non-classic, non-genomic, extra-nuclear or rapid signaling pathway that is mediated by estrogen-binding proteins associated with the plasma membrane and employs various cytoplasmic signaling proteins, growth factor receptors and G-protein-coupled-receptor signaling pathways (Segars \& Driggers, 2002; Driggers \& Segars, 2002; Kelly \& Levin, 2001; Levin, 2002; Hammes \& Levin, 2007).

Pietras and Szego first described the rapid estrogen signaling almost 40 years ago (Pietras \& Szego, 1975 \&1977), noting immediate calcium fluxes in endothelial cells induced by E2 $\beta$ and specific binding sites at the cell surfaces of isolated endothelial cells. Rapid estrogen responses were also recorded in neuroendocrine tissue such as a rapid rise of intracellular calcium in pituitary cells, which leads to cell depolarization within one minute (Dufy et al., 1979). Rapid estrogen signaling also induces prolactin secretion from pituitary tumor cells (Watson et al., 1999). Such signaling of estrogens has also been described in uterine (Aronica et al., 1994) and ovarian cells (Morley et al., 1992; Tesarik \& Mendoza, 1997) as well as bone (Endoh et al., 1997; Longo et al., 2004; Sylvia et al., 2001), vascular endothelial (Russell et al., 2000; Lu et al., 2004) and neuronal cells (Kelly et al., 1976 \& 1977; Mermelstein et al., 1996), indicating that rapid, non-genomic estrogen signaling is involved in various physiological and pathological estrogen activities.

Non-genomic estrogen signaling has been also documented in breast cancer cells for cell proliferation and survival (Migliaccio et al., 1996; Ahmad et al., 1999; Castoria et al., 1999 \& 2001; Lobenhofer et al., 2000; Song et al., 2002). These findings strongly suggest that the rapid, non-genomic estrogen signaling is involved in estrogen-induced proliferation in breast cancer cells.

3. Receptors that mediates rapid estrogen signaling

While it is clear that membrane-initiated estrogen signaling exists, the identity of the ER that mediates these rapid estrogen effects, especially the effects in mammary epithelial cell proliferation and survival, has not been fully established.

\subsection{ER- $\alpha$ and ER- $\beta$}

Immunofluorescent staining of non-permeabilized pituitary tumor cells with anti-ER- $\alpha$ antibodies revealed a punctuated staining pattern on the cell surface although most ER- $\alpha$ were still localized in the cell nuclei (Watson et al., 1999). ER- $\alpha$ associated with the plasma membrane is also detected by a panel of antibodies targeting different domains of ER- $\alpha$ in intact breast cancer cells and in breast cancer specimens (Pietras et al., 2005; Kim et al., 2006). Laboratory evidence indicated that both ER- $\alpha$ and ER- $\beta$ are involved in the rapid estrogen signaling; transient transfection of the nuclear ER- $\alpha$ cDNA into ER-"null" Chinese hamster ovary (CHO) cells leads to expression of both membrane and nuclear ER- $\alpha$. Thus, it is postulated that the membrane-associated ER- $\alpha$ is derived from the same transcript as the nuclear ER- $\alpha$ (Razandi et al., 1999). However, there is evidence indicating that the native, nontransfected CHO-K1, Rat2-fibroblasts and COS7 cells previously considered as ER "null' cells 
and extensively used to transfect ER cDNAs in order to demonstrate rapid estrogen signaling actually exhibit strong rapid estrogen signaling such as activation of the MAPK/ERK (Nethrapalli et al., 2005), suggesting these cells already posses some unknown proteins other than classical ERs that mediate the rapid estrogen signaling.

Experimental evidence also suggests that more than one rapid signaling pathway is associated with estrogen action. Data from several laboratories using the membraneimpermeable compound E2 $\beta$ conjugated with bovine serum albumin (E2 $\beta$-BSA) indicates the existence of two functionally distinct pathways: one sensitive to anti-estrogens and one resistant (Chen et al., 1999; Russell et al., 2000; Watters et al., 1997). For example, ER- $\alpha /$ knockout mice retained rapid estrogen-stimulated membrane effects in neurons, which were not blocked by antiestrogen ICI-182, 780 (Gu, et. al., 1999). These findings suggest that another membrane-based ER may exist since all known ERs are sensitive to anti-estrogen inhibition. As a consequence, an orphan G-protein coupled receptor, GPCR30, and some other unknown proteins have been reported to mediate this anti-estrogen resistant rapid estrogen signaling.

\subsection{GPR30/GPER}

An orphan G-protein coupled receptor, GPR30, was reported to mediate the rapid, nongenomic estrogen signaling that was insensitive to ICI 182,780; estrogen stimulates changes of $\mathrm{Ca}^{2+}$ currents and cAMP signaling in cells expressing GPR30 (Revankar et al., 2005) and activates the MAPK/ERK phosphorylation and the PI3K/AKT signaling pathways via transactivation of the EGFR pathway in ER-negative but GPR30-positive breast cancer cells (Filardo et al., 2000 \& 2007). Thus, GPR30 was considered as a novel type of membraneassociated ER that mediates the rapid, non-genomic estrogen signaling (Prossniz and Barton 2011; Barton 2012). Now, GPR30 is included in the official GPCR nomenclature and was named $\mathrm{G}$ protein-coupled estrogen receptor, GPER, by the International Union of Pharmacology in 2007.

However, there are reports that challenge the role of GPR30/GPER as a novel ER. A study showed that introduction of GPR30/GPER anti-sense oligonucleotides failed to block the MAPK/ERK activation and cell growth induced by E2 $\beta$ in ER-positive breast cancer cells (Ahola et al., 2002). Pedram et al. (2006) failed to observe the cAMP increase or ERK activation in GPR30/GPER-positive and ER-negative breast cancer cells. Another study demonstrated that the GPR30/GPER selective agonist G1 failed to exert estrogenic effect in two classical estrogen target organs, the uterus and the mammary gland (Otto et al., 2008). Later, Otto et al. generated GPR30/GPER-deficient mice and demonstrated that the development of reproductive organs was unimpaired in these mice and the estrogenic responses in the uterus and the mammary gland were completely maintained in GPR30/GPER-deficient animals (Otto et al., 2009). Thus, the possibility that GPR30/GPER might act as a "collaborator" of rapid estrogen signaling ahs been proposed (Albanito et al., 2007; Gao et al., 2011).

\subsection{ER-X}

Another membrane-associated ER with an estimated molecular weight of 63-65 kDa, referred to as ER-X, has been reported (Toran-Allerand et al., 2002). ER-X is developmentally regulated differently from both ER- $\alpha$ and $-\beta$. Its pharmacological profile was also different from ER- $\alpha$ and $-\beta$, even with some features opposite to those shown for these two receptors For examples, ER-X mediated rapid estrogen signaling was not sensitive to anti-estrogen, and the association of Hsp90 is required for the inactive state of ER- $\alpha$ while ER-X requires to be 
associated with Hsp90 for its activity (Toran-Allerand et al., 2002; Toran-Allerand 2005).

\section{4. pER}

A heterodimeric estrogen-binding protein, referred to as the putative ER (pER), was reported to bind to E2 $\beta$ at a sub-nanomolar affinity but was unable to bind other estrogens or anti-estrogens. Depending on cell types, pER is expressed on the plasma and/or nuclear membranes or in the cytoplasm and the nucleus (Rao et al., 1998). Since the polyclonal anti-pER antibody failed to react with ERs and was unable to detect pER expression in reproductive organs (Rao et al., 1998), the role of this putative ER in rapid estrogen signaling of breast cancer cells remains elusive.

\subsection{ER- $\alpha 46$}

Previously, it was reported that a $46-\mathrm{kDa}$ antigen is tightly associated with ER- $\alpha$ in human breast cancer samples (Diaz-Chico et. al., 1988). This 46-kDa antigen is enriched in the cell cytosol and could be recognized by an isolated monoclonal antibody, E476, raised against the human ER- $\alpha$ (Diaz-Chico et. al., 1988). Similarly, Jozan (1991) later reported that there are two species of ER with different molecular weight (65 and $47 \mathrm{kDa}$ ) that were differentially expressed in three types of breast tumors (36\% containing the highest form of ER alone, $49 \%$ bearing the two forms in variable amounts, and $15 \%$ bearing only the minor form). These results strongly suggest that two different forms of ER- $\alpha$ exist at different ratios in human breast cancer. In 2000, Flouriot et. al. cloned a 46-kDa isoform of ER- $\alpha$ and demonstrated that the 46-kDa isoform lacks the first 173 amino acids (A/B or AF-1 domain) and is derived from alternative splicing of the ER- $\alpha$ gene by skipping exon 1 . This alternative splicing event generates an mRNA that has an AUG in a favorable Kozak sequence for translation initiation in frame with the remainder of the open reading frame of ER- $\alpha$ (Flouriot et. al., 2000). This new isoform of ER- $\alpha$ is named as ER$\alpha 46$ and the full-length ER- $\alpha 66$. ER- $\alpha 46$ forms homo-dimers and binds to an ERE, and it can also form heterodimers with ER- $\alpha 66$ (Flouriot et. al., 2000). Furthermore, the ER- $\alpha 46 / 66$ heterodimers form preferentially over the ER- $\alpha 66$ homodimers and ER- $\alpha 46$ acts competitively to inhibit transactivation mediated by the AF-1 domain of ER- $\alpha 66$ but without effect on AF-2dependent transactivation (Floutiot et. al., 2000). Therefore, ER- $\alpha 46$ is a naturally occurring isoform of ER- $\alpha$ that regulates genomic estrogen signaling mediated by the AF-1 domain of ER$\alpha 66$.

Previously, two forms of ER- $\alpha$, full-length (66-kDa) and short form (46-kDa) were copurified with 5' nucleotidase, a plasma membrane-marker enzyme (Marquez \& Pietras, 2001), suggesting a possible role of ER- $\alpha 46$ in the rapid, non-genomic estrogen signaling. ER- $\alpha 46$ was found at the plasma membrane, in the cytosol, and nucleus of endothelial cells and mediated rapid estrogen signaling such as activation of the Src/PI3K/AKT signaling and stimulation of NO synthesis (Kim \& Bender, 2005; Li et. al., 2003; Reviewed by Moriarty et al., 2006), further indicating that the ER- $\alpha 46$ isoform is involved in rapid estrogen signaling.

\section{A novel ER- $\alpha$ variant, ER- $\alpha 36$}

In 2005, our laboratory identified a $5.4 \mathrm{~kb}$ cDNA clone from a normal human edometrium cDNA library (RZPD clone number: DKFZp686N23123) and later cloned this cDNA from a human placenta cDNA library (Wang et al., 2005). This cDNA clone harbors a 310 amino acid open-reading frame that can produce a protein with a predicted molecular weight 
of $35.7 \mathrm{kDa}$. To differentiate it from ER- $\alpha 66$ and 46, and apply consistent nomenclature, this novel isoform of ER- $\alpha$ was named as ER- $\alpha 36$. The cDNA sequence of the open-reading frame matches $100 \%$ to the DNA sequence of the exons 2 to 6 of the ER- $\alpha 66$ gene. The 5'untraslated region (5'UTR) of the cDNA showed $100 \%$ homology to the DNA sequence of the first intron of the ER- $\alpha 66$ gene. Thus, the transcript of this ER- $\alpha$ isoform is initiated from a previously unidentified promoter in the first intron of the ER- $\alpha 66$ gene (Figure 1, Zou et al., 2009). A small, non-coding novel exon in the first intron of the ER- $\alpha 66$ gene was designated as exon 1'. The exon 1' is then spliced directly into the exon 2 of the ER- $\alpha 66$ gene and continues from exon 2 to exon 6 of the ER- $\alpha 66$ gene. Exon 6 is then spliced to an exon located 64,141 bp downstream of the ER- $\alpha 66$ gene (Figure 1). The cDNA sequence encoding the last 27 amino acids and the 4,293 bp 3'untranslated region (3'UTR) was matched $100 \%$ to a continuous sequence from the genomic sequence of clone RP1-1304 on chromosome 6q24.2-25.3 (GeneBank accession number AL78582), indicating the remaining cDNA sequence of this novel ER- $\alpha$ isoform is transcribed from one exon of 4,374 bp located downstream of the ER- $\alpha 66$ gene. This exon is thus designated as exon 9 to reflect the extra exon beyond the previous reported eight exons for ER-a66 gene (Figure 1). All of these splicing events are supported by the identification of perfect splice donors and acceptors at the splice junctures. The protein ER- $\alpha 36$ is produced from a perfect Kozak sequence located in the second exon, the same initiation codon used to produce ER- $\alpha 46$ protein (Flouriot et. al., 2000). ER- $\alpha 36$ differs from the ER- $\alpha 66$ by lacking both transcriptional activation domains (AF-1 and AF-2) but retaining the DNA-binding and dimerization domains, and partial ligand-binding domains. It also possesses an extra, unique 27 amino acid domain to replace the last 138 amino acids encoded by exon 7 and 8 of the ER- $\alpha 66$ (Figure 2). Thus, ER- $\alpha 36$ is another naturally occurring novel isoform of ER- $\alpha$ that may play an important role in both genomic and non-genomic estrogen signaling. Currently, there are three major ER- $\alpha$ isoforms observed in ER-positive breast cancer MCF7 cells that correspond to three mRNA variants generated from different promoter usage and alternative splicing (Figure 2).

\section{Functional interactions of ER- $\alpha 36$ and other ERs}

Comparison of protein structures of ER- $\alpha 66$ and ER- $\alpha 36$ indicated that ER- $\alpha 36$ lacks both AF-1 and -2 transcription activation domains but retains the DNA-binding domain and dimerization domain. Transient co-transfection assays using a luciferase-expressing reporter construct that contains two Estrogen Response Element (ERE) placed upstream of the thymidine kinase promoter $(2 \mathrm{X}$ ERE-tk-Luc) revealed that ER- $\alpha 36$ has no intrinsic transcriptional activity in the presence and absence of E2 $\beta$ (Wang et al., 2006). However, ER- $\alpha 36$ strongly inhibited the transactivation activities mediated by the AF- 1 and -2 domains of both ER- $\alpha 66$ and ER- $\beta$ (Wang et al., 2006). These findings indicate that ER- $\alpha 36$ lacks intrinsic transcription activity. However, ER- $\alpha 36$ acts as a naturally occurring dominant-negative regulator of the genomic estrogen signaling mediated by the AF1 and AF2 domains of ER- $\alpha 66$ and ER- $\beta$.

Currently, the mechanisms by which ER- $\alpha 36$ inhibits genomic estrogen signaling are not clear. ER- $\alpha 36$ retains protein dimerization domains and is able to form heterodimers with ER$\alpha 66$ or ER- $\beta$, which may block transcription activities of both ER- $\alpha 66$ and ER- $\beta$. Alternatively, ER- $\alpha 36$ may bind to the same ERE DNA sequences as ER- $\alpha 66$ and ER- $\beta$ through its intact DNA binding domains and compete with ER- $\alpha 66$ and ER- $\beta$ for DNA binding. Previously, we found that breast cancer tissues expressing high levels of ER- $\alpha 36$ exhibited cytoplasmic staining 
of ER- $\alpha 66$ (Lee et. al., 1999). The same cytoplasmic expression pattern of ER- $\alpha 66$ was also observed in ER-positive breast cancer MCF7 cells transfected with an ER- $\alpha 36$ expression vector (Yin and Wang, unpublished observations). Thus, it is possible that ER- $\alpha 36$ may retain ER- $\alpha 66$ in the cell cytoplasm to block its genomic signaling in the cell nucleus.

Transcription of ER- $\alpha 36$ is initiated from a previously unidentified promoter in the first intron of the ER- $\alpha 66$ gene (Figure 1). The putative 5'-flanking region of the ER- $\alpha 36$ has been cloned and sequenced (Zou et al., 2009). Computer analysis revealed a TATA binding protein (TBP) recognition sequence upstream of the cDNA start site and several Sp1, NF-kB and AP-1 binding sites in the 5'-flanking region of ER- $\alpha 36$. A perfect half ERE site was identified at the promoter region of ER- $\alpha 36$ that is involved in suppression of ER- $\alpha 36$ promoter activity by ER$\alpha 66$, indicating that ER- $\alpha 36$ expression is subjected to negative regulation of ER- $\alpha 66$ (Zou et al., 2009). ER- $\alpha 46$ that lacks the AF-1 domain, however, had no effect on ER- $\alpha 36$ promoter activity and ER- $\alpha 46$ released the suppression activity of ER- $\alpha 66$ when co-expressed with ER$\alpha 66$ (Zou et al., 2009). Thus, ER- $\alpha 66$ suppresses the promoter activity of ER- $\alpha 36$ presumably through the ligand-independent activity mediated by its AF1 domain, which can be blocked by ER- $\alpha 46$. In addition, co-expression of ER- $\alpha 36$ that lacks AF-1 domain also released the suppression activity ER- $\alpha 66$ (Zou et al., 2009), suggesting that ER- $\alpha 36$ expression may be regulated also by a positive-feedback mechanism.

Taken together, ER- $\alpha 36$ blocks the genomic estrogen signaling of ER- $\alpha 66$ and ER- $\beta$ while ER- $\alpha 66$ suppressed the promoter activity of ER- $\alpha 36$, which can be released by ER- $\alpha 46$ and ER- $\alpha 36$ itself. In addition, ER- $\alpha 46$ blocks the transcription activity of the AF-1 domain of ER- $\alpha 66$. Thus, the relative expression levels of ER- $\alpha 66,46$ and 36 in a specific cell determine rations of genomic or non-genomic estrogen signaling.

\section{Biology of ER- $\alpha 36$}

The fact that ER- $\alpha 36$ posses no intrinsic transcription regulatory activity suggests that ER- $\alpha 36$ may mediate rapid estrogen signaling. The sub-cellular fractionation assay in ER- $\alpha 36$ transfected HEK293 cells revealed that a high percentage of ER- $\alpha 36(\sim 50 \%)$ is localized at the plasma membrane and a low percentage of it in cytosol $(\sim 40 \%)$ and nucleus $(\sim 10 \%)$ (Wang et al., 2006). Immuno-fluorescence staining of intact breast cancer MCF7 cells and endometrial cancer Hec1A cells using an ER- $\alpha 36$ specific antibody that recognizes the last 20 amino acids that are unique to ER- $\alpha 36$ exhibits a membrane expression pattern that is co-localized with caveolin-1, a typical cell-surface protein (Lin et. al., 2010). Immunohistochemistry analysis of specimens from breast cancer patients also demonstrated an expression pattern of ER- $\alpha 36$ predominantly outside of the cell nucleus (Lee et al., 2008; Vranic et al., 2011). This anti-ERQ36 specific antibody also blocked rapid estrogen signaling such as activation of the MAPK/ERK signaling in breast cancer cells presumably through steric hindrance of estrogen accesses to its binding pocket (Kang et. al., 2010b), indicating that the antibody is accessible to the C-terminal region of the plasma membrane-associated ER- $\alpha 36$ in intact cells and ER- $\alpha 36$ is important in rapid estrogen signaling. These results thus demonstrated that ER- $\alpha 36$ is expressed on or near the plasma membrane and suggested that ER- $\alpha 36$ may be also shuttled to the cell cytoplasm and nucleus depending on cell context and extracellular signals.

Both E2 $\beta$ and BSA-conjugated E2 $\beta$ elicit the rapid estrogen signaling such as activation of the MAPK/ERK signaling pathway and stimulation of cell proliferation in ER- $\alpha 36$ transfected 
HEK293 cells, which is not blocked by anti-estrogens such as tamoxifen, 4-hydroxy-tamoxifen and ICI 182, 780 (Wang et al., 2006). In addition, other estrogens including estrone (E1), 17 $\alpha$ estradiol (E2 $\alpha)$, estriol (E3) and estetrol (E4) all activate the ERK1/2 phosphorylation at a very similar level as E2 $\beta$, indicating that ER- $\alpha 36$ possess a broader ligand-binding spectrum than ER$\alpha 66$ (Wang et al., 2006). Previously, it was reported that ER- $\alpha 36$ even mediated testosteronestimulated activation of the MAPK/ERK and PI3K/AKT signaling pathways in endometrial cancer Hec1A cells (Lin et al., 2009). ER- $\alpha 36$ also mediates estrogen activation of the

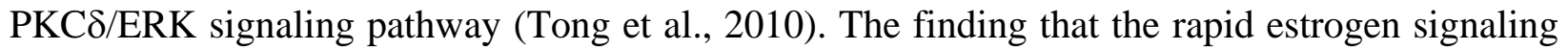
mediated by ER- $\alpha 36$ was insensitive to anti-estrogens suggests that ER- $\alpha 36$ may be a receptor involved in the anti-estrogen-insensitive estrogen signaling described in different systems before. Taken together, ER- $\alpha 36$ is a novel ER that mediates rapid, non-genomic estrogen signaling.

\section{ER- $\alpha 36$ in ER-positive breast cancer and anti-estrogen resistance}

ER- $\alpha$ (ER- $\alpha 66)$ is the most widely used marker in diagnosis of human breast cancer. Breast cancers are diagnosed either as ER-positive or-negative depending on the existence or absence of ER- $\alpha 66$. At the onset, $46 \%-77 \%$ of breast cancers are ER-positive (Roberson et. al., 1996) and up to $70 \%$ of them respond to anti-estrogen therapy (Clark et. al., 2000). The ERpositive tumors are usually histologically well differentiated and diploid, and patients with ERpositive tumors generally have a better prognosis since they respond well to anti-estrogen treatment (Clark et. al., 1984; Osborne et. al., 1980; Clark et. al., 2000).

Since mitogenic estrogen signaling plays a pivotal role in development and maintenance of ER-positive breast cancer, treatment with anti-estrogens such as tamoxifen has become a firstline therapy for advanced ER-positive breast cancer. However, laboratory and clinical evidence indicated that tamoxifen and its metabolites such as 4-hydroxy-tamoxifen have mixed agonist/antagonist or estrogenic/anti-estrogenic actions depending on cell and tissue context, and the agonist activity of tamoxifen may contribute to tamoxifen resistance observed in almost all patients treated with tamoxifen. As a consequence, a more potent and "pure" anti-estrogen, ICI 182, 780 (Fulvestrant, Faslodex) has been developed (Reviewed by Howell et al., 2000).

ICI 182, 780 binds to ERs, impairs receptor dimerization and inhibits nuclear localization of receptor (Fawell, et. al., 1990; Dauvois et. al., 1992). In addition, ICI 182, 780 also accelerates degradation of the ER- $\alpha 66$ protein without a reduction of ER- $\alpha 66$ mRNA (Nicholson et. al., 1995). Thus, ICI 182, 780 binds ER- $\alpha 66$ and accelerates degradation of ER- $\alpha 66$ protein, resulting in a complete inhibition of estrogen signaling mediated by ER- $\alpha 66$. However, ICI 182, 780 failed to induce degradation of ER- $\alpha 36$ (Kang et al., 2010a) presumably because ER- $\alpha 36$ has a truncated ligand-binding domain that lacks the last 4 helixes (helix 9-12) of ER- $\alpha 66$ (Wang et al., 2005). The helix-12 domain is critical in protein degradation induced by ICI 182, 780 and different positioning of the helix 12 and the F domain of ER- $\alpha 66$ regulates functional differences between agonists and antagonists (Mahfoudi et al., 1995; Pearce et al., 2003). Indeed, ER- $\alpha 36$ mediates agonist activities of tamoxifen and ICI 182, 780 in ER-negative breast cancer cells that express high levels of ER- $\alpha 36$ (Zhang et al., 2012).

It is well-known that most breast tumors are eventually resistant to anti-estrogen therapy despite the significant anti-neoplastic activities of anti-estrogens. Essentially, two forms of antiestrogen resistance occur: de novo and acquired resistance (Reviewed by Clarke et. al., 2001 \& 2003; Ring \& Dowestt, 2004). Although absence of ER- $\alpha 66$ expression is the most common de novo resistance mechanism, about 40-50\% ER-positive tumors are already resistant to tamoxifen 
by the time of diagnosis; this de novo resistance mechanism in these ER-positive tumors is largely unknown (Reviewed by Clarke et. al., 2001 \& 2003; Ring \& Dowestt, 2004). In addition, most initially responsive breast tumors gradually acquire anti-estrogen resistance by loss of antiestrogen responsiveness. Breast tumors with acquired tamoxifen resistance frequently but not always retain levels of ER- $\alpha 66$ expression that would still define them as ER-positive tumors (Reviewed by Clarke et. al., 2001 \& 2003). Therefore, a loss of ER- $\alpha 66$ expression is not the major mechanism driving acquired anti-estrogen resistance. Up-regulation of growth factor receptor such as Erb-B2 (Her2/Neu) and constitutive activation of the MAPK signaling pathway, which usually bypass the requirement of estrogen signaling for cell proliferation was found to be involved in development of anti-estrogen resistance (Reviewed by Clarke et. al., 2001 \& 2003; Ring \& Dowsett, 2004).

Previously, a retrospective study of 896 cases of breast cancer patients revealed that about $40 \%$ cases of total human breast cancer patients were positive for ER- $\alpha 36$; about $40 \%$ cases ER-positive breast cancer co-expressed ER- $\alpha 66$ and ER- $\alpha 36$ and about $40 \%$ cases of ERnegative breast cancer that lacked ER- $\alpha 66$ expression were positive for ER- $\alpha 36$ (Shi et al., 2009). The breast cancer patients with tumors expressing high levels of ER- $\alpha 36$ less benefited from tamoxifen therapy than those with low levels of ER- $\alpha 36$ expression did, and ER- $\alpha 36$ expression is significantly associated with Her2/Neu expression (Shi et. al., 2009). These results suggest that enhanced levels of ER- $\alpha 36$ expression in breast cancer cells is one of the underlying mechanisms of de novo tamoxifen resistance found in ER-positive breast cancer patients.

ER-a36-mediated rapid estrogen signaling is insensitive to anti-estrogens such as tamoxifen and ICI 182, 780 (Wang et al., 2006). ER- $\alpha 36$ also mediates agonist activities of tamoxifen and ICI 182, 780 such as activation of the MAPK/ERK and the PI3K/AKT signaling pathways in breast and endometrial cancer cells (Wang et. al., 2006; Lin et. al., 2010; Zhang et al., 2012 \& 2013). In cells expressing ER- $\alpha 36$, the effects of both 4-hydoxytamoxifen and ICI 182, 780 exhibited a non-monotonic, or biphasic dose response curve; anti-estrogens at low concentrations, elicited a mitogenic signaling pathway to stimulate cell proliferation while at high concentrations, anti-estrogens inhibited cell growth (Zhang et al., 2012). Thus, ER- $\alpha 36$ is involved in anti-estrogen resistance by mediating agonist activities of anti-estrogens.

In ER-positive breast cancer cells, it has been well documented that the cross communication between EGFR and ER- $\alpha 66$ leads to phosphorylation of ER- $\alpha 66$ and ligandindependent activation of the ER- $\alpha 66$-mediated transcription (Kato et al., 1995; Bunone et al., 1996). Conversely, EGF signaling is strongly enhanced by the ER- $\alpha 66$ in ER-positive MCF7 cells and anti-estrogen ICI 182, 780 was able to block the EGF signaling (Migliaccio et al., 2006). In addition, our group has reported another level of cross-talk mechanism: positive regulatory loops between ER- $\alpha 36$ and EGFR/HER2 in ER-negative breast cancer cells (Zhang et al., 2011; Kang et al., 2013). In triple-negative breast cancer MDA-MB-231 and MDA-MB-436 cells, knockdown of ER- $\alpha 36$ expression enhances EGFR protein degradation through the proteasome system while the EGFR signaling pathway up-regulates the promoter activity of ER$\alpha 36$ through an AP-1 binding site in the 5' flanking sequence of ER- $\alpha 36$ gene (Zhang et al., 2011). In HER2 over-expressing breast cancer SKBR3 cells, ER- $\alpha 36$-mediated signaling positively regulates HER2 transcription while HER2 signaling up-regulates the promoter activity of ER- $\alpha 36$ (Kang et al., 2013). These results are consistent with the findings that ER- $\alpha 36$ expression is significantly correlated with Her-2/Neu expression in breast cancer (Shi et al., 2009) and with EGFR expression in endometrial cancer (Tu et al., 2011). ER- $\alpha 36$ was found to 
be necessary for both EGFR membrane localization and E2 $\beta$-mediated stimulation of EGFR expression in TCam-2 cells (Wallacides et al., 2012). Thus, the interplay between growth factor receptors and ER- $\alpha 36$ may play an important role in development and progression of subsets of breast cancer that highly express ER- $\alpha 36$ and development of anti-estrogen resistance.

Many researches were conducted to understand the molecular pathways involved in acquired tamoxifen resistance and have revealed that multiple signaling molecules and pathways such as EGFR and HER2 are involved (Clarke et al., 2001 \& 2003; Normanno et al., 2005). Gained signaling through these pathways often bypasses the requirement of estrogen signaling for growth of ER-positive breast cancer cells. Recently, we found that tamoxifen induced ER$\alpha 36$, EGFR and HER2 expression through the positive regulatory loops between ER- $\alpha 36$ and EGFR/ HER2 in tamoxifen sensitive ER-positive breast cancer MCF7 cells (Yin et al., 2014). Thus, the ER- $\alpha 36$-EGFR/HER2 positive regulatory loops are one of the underlying mechanisms of ER-positive breast cancer cells gained expression of the growth factor receptors during tamoxifen treatment.

\section{ER- $\alpha 36$ in ER-negative breast cancer and chemotherapy resistance}

Because of the lack of ER- $\alpha 66$ expression, it is prevailingly thought that estrogen signaling is not involved in development and progression of ER-negative breast cancer. However, early study showed that ovariectomy prevents formation of both ER-positive and negative breast cancers (Nissen-Meyer, 1964). In addition, BRCA1 mutation related tumors, the vast majority of which are ER-negative, are also effectively prevented by prophylactic ovariectomy (Rebbeck et al., 1999). The increased risk developing breast cancer following pregnancy is assumed due to the ability of pregnancy-associated hormones such as estrogen to stimulate mammary epithelial cell proliferation (Gupta et al., 2007). Surprisingly, however, the majority of breast cancers that developed following pregnancy are negative for either estrogen and progesterone receptors (Gupta et al., 2007). Rapid activation of the PI3K/Akt pathway in ER-negative breast cancer MDA-MB-231 cells that could not be blocked by estrogen antagonists was reported (Tsai et. al., 2001), which was explained as estrogen signaling through an ERindependent pathway. Taken together, these reports suggest that subsets of ER-negative breast cancer cells retain rapid estrogen signaling which may contribute to development and progression of ER-negative breast cancers. Several studies demonstrated that ER- $\alpha 36$ variant is expressed in established ER-negative breast cancer cell lines such as MDA-MB-231 and MDAMB-436 and about 40\% specimens from ER-negative breast cancer patients (Wang et al., 2006; Lee et al., 2008; Shi et al., 2009). ER- $\alpha 36$ is commonly over-expressed in apocrine and adenoid cystic carcinomas of the breast, most of which lack ER- $\alpha 66$ and thus are ER-negative (Vranic et al., 2011). Pelekanou et al., (2011) also reported that triple-negative breast cancers that lack expression of ER- $\alpha 66$, progesterone receptor and HER2 highly express ER- $\alpha 36$. Thus, results from different laboratories indicated that subsets of ER-negative breast cancer still express the ER- $\alpha 36$ variant although lack expression of ER- $\alpha 66$. These ER-negative breast cancers may still response to mitogenic estrogen signaling.

Chaudhri et al., (2012) reported the presence of ER- $\alpha 36$, in ER-positive MCF7 and ERnegative HCC38 breast cancer cells, that localized to the plasma membrane and rapidly activated PKC in response to E2 $\beta$, leading to deleterious effects such as enhancement of proliferation, protection against apoptosis, and enhancement of metastatic factors (Chaudhri et al., 2012). Our group also found that E2 $\beta$ treatment activated the MAPK/ERK signaling pathway, induced 
expression of growth-promoting genes, c-Myc and cyclin D1, stimulated cell proliferation and accelerated tumor growth in vivo in ER-negative breast cancer MDA-MB-231 and MDA-MB436 cells, all of which could be abrogated by knockdown of ER- $\alpha 36$ expression using the ER$\alpha 36$ specific shRNA (Zhang et al., 2011). Knockdown of ER- $\alpha 36$ expression also disrupted the ER- $\alpha 36-E G F R / H E R 2$ positive regulatory loops in ER-negative breast cancer cells and inhibited growth of these cells (Zhang et al., 2011; Kang et al., 2012) Thus, ER- $\alpha 36$-mediated rapid estrogen signaling and the ER- $\alpha 36-E G F R / H E R 2$ positive regulatory loops are involved in malignant growth of ER-negative breast cancer.

Recently, Yu et al., (2014) reported that breast cancer patients with tumors highly expressing ER- $\alpha 36$ less benefited from neoadjuvant chemotherapy and have worse prognosis, It was suggested that ER- $\alpha 36$ may be used as a predictive biomarker for the efficacy of neoadjuvant chemotherapy, and the negative expression of ER- $\alpha 36$ may be a favorable factor of prognosis in breast cancer patients treated with neoadjuvant chemotherapy.

\section{ER- $\alpha 36$ in breast cancer stem/progenitor cells}

Accumulating experimental and clinical evidence supports that breast cancer may arise from mammary stem/progenitor cells which posses the ability to self-renew (Al-Hajj et al., 2003; Dontu et al., 2003; Charafe-Jauffret et al., 2009; Oliveira et al., 2010). Al-Hajj et al, enriched a $\mathrm{CD} 44^{+} / \mathrm{CD} 24^{-/ \text {low }}$ cell population from human breast cancer that displayed cancer stem/progenitor cell properties and was capable of forming tumors in immuno-compromised mice with higher efficiency than cells with alternative phenotypes. Later, aldehyde dehydrogenase (ALDH) 1 expression and/or its activity were identified to be a marker for breast cancer stem/progenitor cells; fewer ALDH1 positive tumor cells than $\mathrm{CD}_{4} 4^{+} / \mathrm{CD} 24^{-/ \text {low }}$ tumor cells are required to generate tumors in vivo (Ginestier et al., 2007). The breast cancers with ALDH $1^{\text {high }}$ cancer stem-like cells are associated with more aggressive phenotypes such as ER negativity, high histological grade, HER2 positivity, as well as poor prognosis (Morimoto, et al., 2009).

Many signaling pathways involved in regulation of normal mammary stem cells including Hedgehog, Bmi-1, Wnt, NOTCH, HER-2, p53 and PTEN/Akt/ $\beta$-catenin pathways play roles in breast cancer stem/progenitor cells (Korkaya et al., 2008 \& 2009; Han et al., 2009; Woodward et al., 2007). However, the involvement of estrogen signaling, a major signaling pathway profoundly influences mammary carcinogenesis, in regulation of breast cancer stem/progenitor cells has not been established for a long time, since expression of ER- $\alpha 66$ in breast cancer stem/progenitor cells is controversial. It was reported that stem-like cells isolated from normal mammary gland and breast cancer tissues lack expression of the full-length ER- $\alpha 66$ (Dontu et al., 2004; Sleeman et al., 2007). However, Clarke et. al., (2005) reported that ER- $\alpha 66$ is expressed in putative normal breast stem/progenitor cells enriched by the "side population" method. Despite the fact that ER- $\alpha 66$ expression in mammary stem cells is not clear, the significance of estrogen signaling for normal development and growth of the mammary gland are well established by studies in human and animal, which was explained as though an indirect paracrine pathway (Asselin-Labat et al., 2010; Fillmore et al., 2010; Mallepell et al., 2006). It was also proposed that the status of ER in breast cancer stem cells is dependent on the origin of breast cancer, ER-positive breast cancers originate from transformed ER-positive stem/progenitor cells while ER-negative breast cancers from ER-negative stem/progenitor cells (Dontu et al., 2004). 
Recently, our group found that breast cancer stem/progenitor cells derived from ER-positive breast cancer cells express high levels of ER- $\alpha 36$ (Deng et al., 2014a). Knockdown of ER- $\alpha 36$ expression with the shRNA method in ER-positive breast cancer cells diminished rapid estrogen signaling in ER-positive breast cancer stem/progenitor cells and significantly reduced the percentage of breast cancer stem/progenitor cells (Deng et al., 2014a). ER- $\alpha 36$ expression is well correlated with ALDH1 expression in tumor samples of breast cancer patients (Deng et al., 2014a). In addition, ER- $\alpha 36$ knockdown also decreased ALDH1 positive cell population in ERnegative breast cancer SKBR-3 cells (Kang et al., 2013). Thus, ER- $\alpha 36$ mediated rapid estrogen signaling plays an important role in maintenance of ER-positive and -negative breast cancer stem/progenitor cells.

The major features of cancer stem cells include the ability of self-renewal and generating tumors from very few cells, slow cell division, the ability to produce differentiated cells of different lineages, selective resistance to radio- and chemo-therapy (Dean et al., 2005; Diehn \& Clarke, 2006). The possible involvement of breast cancer stem/progenitor cells in anti-estrogen resistance has been proposed (O'Brien et al., 2013) and demonstrated (Piva et al., 2013); the breast cancer stem/progenitor cells induced by Sox 2 introduction are resistant to tamoxifen. Recently, our laboratory demonstrated that ER- $\alpha 36$ mediated resistance of breast cancer stem/progenitor cells to anti-estrogens tamoxifen and ICI 182, 780 and anti-estrogen stimulation of luminal epithelial lineage specific ER-positive breast cancer progenitor cells (Deng et al., 2014b). Thus, it is possible that anti-estrogen treatment may enrich breast cancer stem/progenitor cells and even stimulate progenitor cell proliferation, which results in failure of anti-estrogen treatment.

\section{ER- $\alpha 36$-mediated rapid estrogen signaling}

10.1 Early events of ER- $\alpha 36$-mediated rapid estrogen signaling

Previously, Razandi et al., reported that HB-EGF released by matrix metalloproteinases (MMP)-2 and -9 that are activated by the $G$ protein-coupled receptors via Src signaling is responsible for estrogen-induced activation of the EGFR and the MAPK/ERK in MCF7 cells (Razandi et al., 2003). Later, Song et al., reported that IGF-IR is also involved in the rapid estrogen signaling of MCF7 cells (Song et al., 2007). Previously, our group reported that ERa36 physically interacts with EGFR in ER-negative breast cancer cells (Zhang et al., 2011). After E2 $\beta$ treatment, ER- $\alpha 36$ was gradually dissociated from the EGFR and associated with Src and Shc, suggesting that ER- $\alpha 36$ might dynamically change its partners with the EGFR/Src/Shc complex during rapid estrogen signaling (Zhang et al., 2011). Recently, our group further reported that E2 $\beta$ induced several cycles of ERK activation in MCF7 cells expressing high levels of recombinant ER- $\alpha 36$ (Zhang et al., 2014). Using neutralizing antibodies, we found that the estrogen-induced first and second peaks of the ERK activation was blocked by the anti-HB-EGF neutralizing antibody while the anti-amphyregulin antibody only blocked the second peak of ERK activation, suggesting HB-EGF is involved in the ERK activation induced by amohyregulin. With neutralizing antibodies, we also demonstrated that IGF-IR, EGFR and HER2 are all involved in the rapid estrogen signaling mediated by ER- $\alpha 36$ in ER-positive breast cancer MCF7 cells (Zhang et al., 2014). Using different chemical inhibitors, we further revealed that Src and MMPs are also involved in the rapid estrogen signaling of ER-positive breast cancer MCF7 cells. Thus, initiation of the rapid estrogen signaling is a highly synchronized process that involves a number of growth factors and their receptors, consistent with the previous view that estrogen acts as growth factors (Migliaccio et al., 2002; Shupnik et al., 2004). Our results thus 
provided a novel mechanism for the functional communication among these signaling pathways; ER-o36 mediates rapid estrogen signaling that employs IGF-1R, EGFR and HER2 (Figure 3).

\subsection{ER- $\alpha 36$ downstream signaling pathways}

Estrogen activation the MAPK/ERK pathways is a typical event of rapid estrogen signaling. Our laboratory reported an increase of ERK1/2 phosphorylation of HEK293 cells transfected with a ER- $\alpha 36$ expression vector after the treatments with E2 $\beta$, and E2 $\beta$-BSA, a membrane-impermeable form of E2 $\beta$ (Wang et al., 1996), indicating that ER- $\alpha 36$ mediates rapid estrogen signaling. Such event was also noticed in ER-negative breast and endometrial cancer cells that express endogenous ER- $\alpha 36$ (Kang et al., 2010; Zhang et al., 2011; Lin et al., 2009; Lin et al., 2010; Ohshiro et al., 2012).

Estrogen activates the ERK1/2 via the PKC (McMillan et al., 2006), rapidly enhancing phosphorylation of proteins that promote proliferation in plate chondrocytes. Tong et al. found that ER- $\alpha 36$ mediated estrogen-induced activation of MAPK/ERK pathway via PKC $\delta$ in endometrial cancer cells (Tong et al., 2010). In breast cancer cells, ER- $\alpha 36$ rapidly activated PKC in response to E2 $\beta$, leading to the increase of proliferation (Chaudhri et al., 2012).

The treatment of estrogen and anti-estrogens led to rapid activation of the MAPK/ERK1/2 and a substantial increase of cell migration and invasiveness in inflammatory microenvironment of breast cancer in the presence of ER- $\alpha 36$ but not ER- $\alpha 66$ (Chaudhri et al., 2012). Estrogen-induced migration and invasiveness were blocked by the MEK inhibitor U0126, indicating that estrogen activation of the ERK1/2 is involved in the regulation of the cell motility and invasiveness (Chaudhri et al., 2012). It was also found the up-regulation of p-ERK1/2 level in tumor samples from patients with inflammatory breast cancer (Ohshiro et al., 2012). Thus, ER- $\alpha 36$-mediated estrogen activation of the MAPK/ERK signaling pathway is involved in proliferation and invasion of inflammatory breast cancer cells.

The c-Jun N-terminal Kinases (JNKs) are other principal members of the MAPK family that regulate cell proliferation, differentiation and migration (Wagner \& Nebreda, 2009). In the absence of ER- $\alpha 36$, the JNKs were less activated and cells were arrested at the G2/M phase after treatment with paclitaxel (Zhang et al., 2012). It seems that ER- $\alpha 36$ attenuates the effect of paclitaxel via the activation of the JNKs pathway and ER- $\alpha 36$-absent cancer cells are more sensitive to paclitaxel.

The serine/threonine kinase (AKT), or protein kinase B, plays an important role in cell proliferation and survival by inhibition of apoptosis in tamoxifen resistant cells (Jordan et al., 2004). Treatments with testosterone, E2 $\beta$, or tamoxifen induced rapid phosphorylation of AKT in Hec1A cells through ER- $\alpha 36$ (Lin et al., 2009). Tamoxifen induced AKT phosphorylation in MCF7 cells transfected with ER- $\alpha 36$ expression vector, which contributes to ER- $\alpha 36$ mediated tamoxifen resistance (Lin et al., 2010; Zhang et al., 2013).

Taken together, these results suggested that most if not all of the signaling pathways downstream of tyrosine kinase receptors are involved in ER-a36-mediated rapid estrogen signaling.

11. ERs in breast cancer: who has the last word?

Experimental and clinical evidence for the role of endogenous estrogens in normal development of mammary glands and breast cancer etiology has been well documented (Reviewed by Feigelson \& Henderson, 1996). Estrogen signaling is involved in mammary epithelial cell proliferation and differentiation. Dysregulated estrogen signaling increases the rate 
of cell proliferation and thus the risk for development of breast cancer. Estrogens function as potent mitogens through promoting cell cycle progression from G1 to S phase (Prall et al., 1998; Altucci et al., 1996 \& 1997). Thus, estrogens directly interact with ERs in ER-positive human breast cancer cells, where they induce transcriptional activation of "immediate early" and cyclin genes, and promote cell cycle progression. This classic estrogen-signaling pathway is prevailingly thought to be responsible for estrogen-stimulated cell proliferation as well as initiation and progression of estrogen-related cancers such as breast and endometrial cancers. Consistent with its role in mammary carcinogenesis, ER- $\alpha 66$ expression is increased at the earliest stages of ductal hyperplasia and increases even more with increasing atypia, such that most cells in atypical ductal hyperplasias and in ductal cancer in situ of low and intermediate grade contain ER- $\alpha 66$ (Khan et. al., 1994).

ER- $\alpha 66$ is expressed in approximately $15-30 \%$ of luminal epithelial cells and not at all in any other cell types in the normal human breast (Clarke et. al., 1997). However, dual label immunofluorescent technique revealed that ER- $\alpha 66$ expressing cells are separate from those labeled with proliferation markers such as Ki67 and cyclin A in both normal human and rodent mammary glands (Clarke et al., 1997; Zeps et al., 1999). As ER- $\alpha 66$ expression increases during breast cancer development, the inverse relationship between ER- $\alpha 66$ expression and cell proliferation become dysregulated (Roger et al., 2000; Shoker et. al., 1999a \& b; Jensen et al., 2001). Approximately $70 \%$ of breast carcinomas express the ER- $\alpha 66$ and most of these tumors contain ER- $\alpha$ positive proliferating cells (Clarke et. al., 1997).

However, the explanation of the mitogenic estrogen signaling simply by the function of ER- $\alpha 66$ is confounding. When ER- $\alpha 66$ was expressed in ER-negative CHO cells (Kushner et al., 1990) and human cervical cancer HeLa cells (Touitou et al., 1990), estrogen did not stimulate cell growth. On the contrary, estrogen inhibited cell growth and even induced cell death. Likewise, the ER-null MCF10A breast epithelial cells (Pilat et al., 1996), and MDA-MB-231 breast cancer cells (Garcia et al., 1992; Barrón-González et al., 2004; Jiang \& Jordan, 1992) were growth inhibited when they were stably transfected with ER- $\alpha 66$ cDNA. These results strongly argue against a positive and direct role of the ER- $\alpha 66$ in estrogen-stimulated cell proliferation.

ER- $\beta$ also acts as a dominant-negative regulator of mitogenic estrogen signaling. ER- $\beta$ expression is decreased in proliferative pre-invasive mammary tumors (Roger et al., 2001). In ER positive cells, ER- $\beta$ attenuates estrogen activities such as transcriptional regulation and stimulation of cell proliferation (Reviewed by Deroo \& Buensuceso, 2010; Harris, 2007; Ogawa et al., 1998; Lazennec et al., 2001; Galluzzo et al., 2007). ER- $\beta$ inhibits the estrogen-induced proliferation in ER-positive breast cancer cells and blocks estrogen-stimulated tumor formation in nude mice (Paruthiyil et al, 2004; Hartman et al., 2006).

ER- $\alpha 46$ is an isoform of ER- $\alpha 66$ that has not been studied extensively. Forced expression of ER- $\alpha 46$ inhibited proliferation of MCF-7 breast cancer cells and cyclin D1 promoter activity (Penot et al., 2005). Overexpression of both ER- $\alpha 46$ and ER- $\alpha 66$ in ERnegative MDA-MB-231 cells revealed that ER- $\alpha 46$ inhibited basal transcription of the estrogen responsive gene pS2 while estrogen treatment released this inhibition (Metivier et al., 2004). Recently, the level of ER- $\alpha 46$ expression was found to be down-regulated in tamoxifen-resistant breast cancer cells and re-introduction of ER- $\alpha 46$ into these cells inhibited cell proliferation and ER- $\alpha 66$-regulated gene transcription (Klinge et al., 2010). Thus, these results suggest that ER$\alpha 46$ may also function as a negative regulator of estrogen-stimulated cell proliferation. 
Taken together, while it is well known that estrogen is a potent mitogen, the identity of the receptor that mediates estrogen-stimulated cell proliferation has not been well established.

Accumulating evidence indicated that the rapid estrogen signaling that involves the MAPK/ERK and the PI3K/AKT signaling pathways mediates proliferative and anti-apoptotic effects of estrogens in a variety of normal and cancer cells (Kelly \& Levin, 2001; Levin 2009; Acconcial \& Marino, 2011). The most intriguing data are those from Auricchio's group. An elegant and extensive series of experiments led to the conclusion that the mitogenic activity of estrogen is exclusively mediated by the rapid estrogen signaling involving Src and the PI3K/AKT pathway in ER-positive breast cancer MCF7 cells (Migliaccio et al., 1996; Castoria et al., $1999 \& 2001)$.

Previous reports have indicated that ER- $\alpha 66$ and ER- $\beta$ mediate the rapid estrogen signaling such as the activation of the MAPK/ERK signaling based on experiments involving transfection of these ER cDNAs into reportedly ER-deficient cell lines such as CHO-K1 (Razandi et al., 1999), COS-7 (Migliaccio et al., 1996), Rat2 fibroblasts (Wade et al., 2001). Later, however, Nethrapalli et al., (2005) demonstrated that estrogen activated the MAPK/ERK signaling in native, non-transfected CHO-K1, COS-7 and RAT2 fibroblast cells. Previously, our laboratory also reported that non-transfected COS-7 cells expressed endogenous ER- $\alpha 36$ and exhibited the rapid estrogen signaling (Kang et al., 2010b) Together, these results suggested that the cells null for ER- $\alpha 66$ used as models to study the rapid estrogen action may already express endogenous ER- $\alpha 36$ and are able to elicit the rapid estrogen signaling.

The membrane-bound ER GPR30/GPER belongs to the G-protein-coupled receptor superfamily was reported to mediate rapid estrogen signaling in different kinds of cells (Revankar et al., 2005; Filardo et al., 2000 \& 2007; Prossnitz and Barton 2011). Our group reported that knockdown of GPR30/GPER expression in ER-negative breast cancer SK-BR-3 cells down-regulated ER- $\alpha 36$ expression (Kang et al., 2010b). Introduction of a GPR30 expression vector into GPR30/GPER non-expressing cells induced endogenous ER- $\alpha 36$ expression and GPR30/GPER activated the promoter activity of ER- $\alpha 36$ via an AP-1 binding site located in the 5'-flanking region of ER- $\alpha 36$ (Kang et al., 2010b). Recently, it has also been reported that E2 stimulates proliferation in the seminoma-like Tcam-2 cells through a GPR30/GPER-dependent induction of ER- $\alpha 36$ (Wallacides et al 2012). In addition, we also observed that ER- $\alpha 36$ physically interacted with GPR30/GPER (Kang and Wang, unpublished observations), suggesting a possible cross-talk between ER- $\alpha 36$ and GPR30/GPER. Functional cross-talk between ER- $\alpha 66$ and GPR30/GPER has been demonstrated in ovarian cancer cells (Albanito et al., 2007). Thus, ER- $\alpha 36$ might be a downstream target gene of GPR30/GPERmediated signaling and the previously reported activities of GPR30/GPER as a membrane-based ER may be partially mediated through its ability to induce ER- $\alpha 36$ expression.

However, Lindsey et al. reported that under disease conditions, GPR30/GPER signaling exhibits renoprotective effects by reducing proteinuria in a model of salt-sensitive hypertension in kidney (Lindsey et al., 2011). These investigators failed to detect ER- $\alpha 36$ expression in the kidney (Lindsey et al., 2011). Thus, it is possible that in the hypertensive renal disease model and the related proteinuria in experimental animals, ER- $\alpha 36$ is not directly involved in the effects mediated by GPR30/GPER signaling. GPR30/GPER may signal dependently or independently on ER- $\alpha 36$ in different systems. Currently, most studies focus on either ER- $\alpha 36$ or GPR30/GPER, it would be more informative to examine cross-talk of both receptors in a suitable system. 
Recently, we used the shRNA specifically targeting ER- $\alpha 66$ or 36 to knock-down expression of ER- $\alpha 66$ or 36 individually and found that the cells with knocked-down levels of ER- $\alpha 36$ expression lacked the rapid estrogen signaling. On the contrary, the cells with ER- $\alpha 66$ expression knocked-down still exhibited the rapid estrogen signaling (Zhang et al., 2014). Thus, our data, for the first time, demonstrated that the ER- $\alpha 36$ is the ER responsible for the rapid estrogen signaling such as the ERK activation in ER-positive breast cancer cells.

Using the ER-positive breast cancer cells with ER- $\alpha 66$ or 36 expression specifically and separately knocked-down, we also found that in ER-positive breast cancer cells, induction of the well-known estrogen responsive and growth-promoting genes such as cyclin-D1, c-Myc and PgR receptor, the ER- $\alpha 66$ target genes without the ERE-like sequence in their promoter regions, were actually through the ER- $\alpha 36$-mediated rapid estrogen signaling while the pS2 gene that contains a perfect ERE site was induced by ER- $\alpha 66$ (Zhang \& Wang, unpublished results). Recently, we reported that estrogen induced cyclin-D1 expression in ER-negative breast cancer cells that only express ER- $\alpha 36$ through the Src/EGFR/STAT5 pathway (Zhang et al., 2013). It was also reported that STAT5, c-Src and EGFR play important roles in estrogen-stimulated proliferation of ER-positive breast cancer cells (Fox et al., 2008). Constitutive activation of STAT5 was detected in a panel of breast cancer cell lines such as MCF7 and T47D cell lines and introduction of a dominant-negative STAT5 into T47D cells inhibited estrogen-stimulated cell growth and induced apoptosis (Yamashita et al., 2003). Thus, estrogen responsive genes are regulated by both rapid and gnomic estrogen signaling pathways, consistent with the hypothesis proposed before that estrogen signaling regulates gene transcription through multiple signaling pathways (Marino et al., 2006; Björnström \& Sjöberg, 2005).

\section{Conclusions}

ER- $\alpha 36$ is a novel isoform of ER- $\alpha 66$ that mainly mediates rapid, non-genomic estrogen effects and inhibits the genomic activity of the nuclear ERs in breast cancer cells. ERa36 utilizes HB-EGF, SRC. EGFR, HER2 and IGF-IR to transduce rapid estrogen signaling by activating downstream signaling pathways. These signaling pathways eventually induce transcription of the growth-promoting genes such as c-Myc and Cyclin D1 and stimulate cell proliferation in breast cancer cells. The findings that ER- $\alpha 36$ is highly expressed in both ERpositive and -negative breast cancer cells, contributes to anti-estrogen resistance and is involved in maintenance of breast cancer stem/progenitor cells, indicate that ER- $\alpha 36$ is a new player that plays an important role in estrogen signaling during initiation and development of breast cancer. Thus, further investigation of the function and underlying mechanisms of ER- $\alpha 36$ in initiation and development of both ER-positive and -negative breast cancer will greatly advance or even change our current knowledge on human breast cancer.

\subsection{Perspectives.}

Most previous studies of estrogen signaling in human breast cancer were focused on the ER- $\alpha 66$, the only known ER for many years. The discovery of ER- $\alpha 36$ in our laboratory, combined with the previous findings of membrane-based ER- $\alpha 46$, raised the intriguing possibility that ER- $\alpha 36$ and ER- $\alpha 46$ are also involved in estrogen signaling. Net estrogen response in a specific target cell thus depends on absolute and relative levels of the regulated expression of full-length and alternatively processed ER- $\alpha$ isoforms.

A plethora of experimental evidence indicates that ER- $\alpha 66$, ER- $\alpha 46$, and ER- $\beta$ 
negatively regulate mitogenic estrogen signaling in transfected cells, which argue against the positive role of these receptors in estrogen-stimulated cell proliferation. Thus far, ER- $\alpha 36$ is the only reported ER that mediates estrogen-stimulated cell proliferation in transfected cells and in ER-negative breast cancer cells that lack expression of ER- $\alpha 66$, ER- $\alpha 46$ and ER- $\beta$ but express high level of endogenous ER- $\alpha 36$. In addition, the finding that ER- $\alpha 36$ functions as a potent dominant-negative regulator of the genomic estrogen signaling mediated by ER- $\alpha 66$ and ER- $\beta$ implicates that when ER- $\alpha 36$ mediates mitogenic estrogen signaling, it may require the silence of genomic estrogen signaling. This again challenges the well-known role of genomic estrogen signaling in estrogen-stimulated cell proliferation.

Accumulating evidence indicates the importance of ER- $\alpha 36$-mediated rapid estrogen signaling in malignant growth of endometrial cancer cells. ER- $\alpha 36$ expression was detected at the plasma membrane and in the cytoplasm of cells in both endometrial cancer tissues and cell lines (Tu et al., 2011; Lin et al., 2009 \& 2010). ER- $\alpha 36$-mediated activation of the MAPK/ERK and PI3K/Akt pathways promoted the proliferation of endometrial cancer cells induced by different ligands, e.g. E2 $\beta$, tamoxifen, or testosterone (Lin et al., 2009 \& 2010; Tong et al., 2010). In addition, ER- $\alpha 36$ expression was positively associated with high stage and grade and poor disease-free survival rate of endometrial cancer cases (Sun et al., 2013). Thus, ER- $\alpha 36$ may be an important biomarker for diagnosis and prognosis of endometrial carcinoma.

ER- $\alpha 36$ expression at the plasma membrane and in the cytoplasm was also detected in different types of human cancer such as colorectal (Jiang et al., 2008), gastric (Deng et al., Wang et al., 2012) and hepatic cancers (Miceli et al., 2011), suggesting that ER- $\alpha 36$ may be involved in initiation and development of human malignancy in non-classical estrogen targeting organs. Elucidating the functions of ER- $\alpha 36$-mediated rapid estrogen signaling in different types of human malignancy could provide more informed approaches to better understand the underlying mechanisms of mitogenic estrogen signaling in mammary carcinogenesis. We hope that future investigation in different subtypes of human breast cancer and in the breast cancer stem/progenitor cells will lead to development of high efficacy, less toxic therapeutic agents for breast cancer patients trough targeting breast cancer stem-like cells.

List of abbreviations:

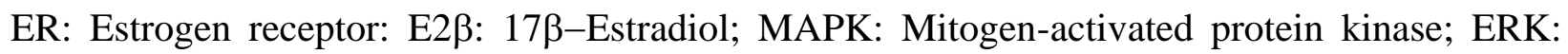
Extracellular signal-regulated kinases; JNK: c-Jun N-terminal Kinase; PI3K: Phosphatidylinositide 3-kinase; EGFR: Epidermal growth factor receptor; HER2: Human Epidermal Growth Factor Receptor 2; IGF-IR: Insulin-like growth factor receptor I; STAT: signal transducer and activator of transcription. GPCR: G protein-coupled receptor; GPER: G protein-coupled estrogen receptor.

Competing interests

All authors declare that they have no competing interests.

Acknowledgements

This work was supported by Department of Defense grant DAMD 11-1-0497 and by Nebraska Tobacco Settlement Biomedical Research Program Awards LB-595 to Z.Y. Wang. 


\section{References}

Acconcial, F., Marino, M. 2011. The effects of $17 \beta$-estradiol in cancer are mediated by estrogen receptor signaling at the plasma membrane. Front Physiol. 2: 1-8.

Ahmad, S., Singh, N., Glazer, RI. 1999. Role of AKT1 in 17beta-estradiol- and insulin-like growth factor I (IGF-I)-dependent proliferation and prevention of apoptosis in MCF-7 breast carcinoma cells. Biochem Pharmacol 58: 425-430.

Ahola, TM., Alkio, N., Manninen, T., Ylikomi, T. 2002. Progestin and G protein-coupled receptor 30 inhibit mitogen-activated protein kinase activity in MCF-7 breast cancer cells. Endocrinology. 143: 4620-4626.

Albanito, L., Madeo, A., Lappano, R., Vivacqua, A., Rago, V., Carpino, A., et al., 2007. G protein-coupled receptor 30 (GPR30) mediates gene expression changes and growth response to 17beta-estradiol and selective GPR30 ligand G-1 in ovarian cancer cells. Cancer Res. 67: 18591866.

Al-Hajj, M., Wicha, MS., Ito-Hernandez, A., Morrison, SJ., Clarke, MF. 2003. Prospective identification of tumorigenic breast cancer cells. Proc Natl Acad Sci USA. 100: 3983-3988.

Altucci, L., Addeo, R., Cicatiello, L., Dauvois, S., Parker, MG., Truss, M., Beato, M., Sica, V., Bresciani, F., Weisz, A. 1996. 17beta-Estradiol induces cyclin D1 gene transcription, p36D1p34cdk4 complex activation and p105Rb phosphorylation during mitogenic stimulation of G1arrested human breast cancer cells. Oncogene. 12: 2315-2324.

Altucci, L., Addeo, R., Cicatiello, L., Germano, D., Pacilio, C., Battista, T., Cancemi, M., Petrizzi, VB., Bresciani, F., Weisz, A. 1997. Estrogen induces early and timed activation of cyclin-dependent kinases 4, 5, and 6 and increases cyclin messenger ribonucleic acid expression in rat uterus. Endocrinology. 138: 978-984.

Aronica, SM., Kraus, WL., Katzenellenbogen, BS. 1994. Estrogen action via the cAMP signaling pathway: stimulation of adenylate cyclase and cAMP-regulated gene transcription. Proc Natl Acad Sci U S A. 91: 8517-8521.

Asselin-Labat, M-L., Vaillant, F., Sheridan, JM., Pal, B., Wu, D., Simpson, ER., Yasuda, H., Smyth, GK., Martin, TJ., Lindeman, GJ., Visvader, JE. 2010. Control of mammary stem cell function by steroid hormone signaling. Nature. 465: 798-802.

Barrón-González A, Castro Romero I. 2004. Re-expression of estrogen receptor alpha using a tetracycline-regulated gene expression system induced estrogen-mediated growth inhibition of the MDA-MB-231 breast cancer cell line. Biochem Cell Biol. 82 (2): 335-342.

Barton, M. 2012. The membrane estrogen receptor GPER-Clues and questions. Steroids, 77: 935-942.

Berry, M., Metzger, D., Chambon, P. 1990. Role of the two activating domains of the oestrogen receptor in the cell-type and promoter-context dependent agonistic activity of the anti-oestrogen 4-hydroxytamoxifen. EMBO J. 9: 2811-2818.

Björnström, L., Sjöberg, M. 2005. Mechanisms of estrogen receptor signaling: convergence of genomic and nongenomic actions on target genes. Mol Endocrinol. 19: 833-842.

Bunone, G., Briand, PA., Miksicek, RJ., Picard, D. 1996. Activation of the unliganded estrogen receptor by EGF involves the MAP kinase pathway and direct phosphorylation. EMBO J. 15: 2174-2183.

Castoria, G., Barone, M.V, Di Domenico, M., Bilancio, A., Ametrano, D., Migliaccio, A., Auricchio, F. 1999. Non-transcriptional action of oestradiol and progestin triggers DNA synthesis. EMBO J. 18: 2500-2510. 
Castoria, G., Migliaccio, A., Bilancio, A., Di Domenico, M., de Falco, A., Lombardi, M., Fiorentino, R., Varricchio, L., Barone, MV., Auricchio, F. 2001. PI3-kinase in concert with Src promotes the S-phase entry of oestradiol-stimulated MCF-7 cells. EMBO J. 20: 6050-6059.

Cerillo, G., Rees, A., Manchanda, N., Reilly, C., Brogan, I., White, A., Needham, M. 1998. The oestrogen receptor regulates NFkappaB and AP-1 activity in a cell-specific manner. J Steroid Biochem. Mol. Biol. 67: 79-88.

Charafe-Jauffret, E., Ginestier, C., Iovino, F., Wicinski, J., Cervera, N., Finetti, P., Hur, MH., Diebel, ME., Monville, F., Dutcher, J., Brown, M., Viens, P., Xerri, L., Bertucci, F., Stassi, G., Dontu, G., Birnbaum, D., Wicha, MS. 2009. Breast cancer cell lines contain functional cancer stem cells with metastatic capacity and a distinct molecular signature. Cancer Res. 69: 302-313. Chaudhri, RA., Olivares-Navarrete, R., Cuenca, N., Hadadi, A., Boyan, BD., Schwartz, Z. 2012. Membrane estrogen signaling enhances tumorigenesis and metastatic potential of breast cancer cells via estrogen receptor-alpha36 (ERalpha36). J Biol Chem. 287: 7169-7181.

Chaudhri, RA., Schwartz, N., Elbradie, K., Schwartz, Z., Boyan, BD. 2014. Role of ERalpha36 in membrane associated signaling by estrogens. Steroids 2012. 81: 74-80.

Chen, Z., Yuhanna, IS., Galcheva-Gargova, Z., Karas, RH., Mendelsohn, ME., Shaul, PW. 1999. Estrogen receptor alpha mediates the nongenomic activation of endothelial nitric oxide synthase by estrogen. J Clin. Invest. 103: 401-406.

Clark, GM., Osborne, CK., McGuire, WL. 1984. Correlations between estrogen receptor, progesterone receptor, and patient characteristics in human breast cancer. J Clin Oncol. 2: 11021109.

Clark, GM. 2000. Prognostic and predictive factors. Diseases of the breast, Lippincott Williams \& Wilkins, Vol. 2: 489-514.

Clarke, RB., Howell, A., Potten, CS., Anderson, E. 1997. Dissociation between steroid receptor expression and cell proliferation in the human breast. Cancer Res. 57: 4987-4991.

Clarke, RB., Leonessa, F., Welch, JN., Skaar, TC. 2001. Cellular and molecular pharmacology of antiestrogen action and resistance. Pharmacol. Rev. 53: 25-71.

Clarke, RB., Liu, MC., Bouker, KB., Gu, Z., Lee, RY., Zhu, Y., Skaar, TC., Gomez, B., O'Brien, K., Wang, Y., Hilakivi-Clarke, LA. 2003. Antiestrogen resistance in breast cancer and the role of estrogen receptor signaling. Oncogene. 22: 7316-7339.

Clarke, RB., Spence, K., Anderson, E., Howell, A., Okano, H., Potten, CS. 2005. A putative human breast stem cell population is enriched for steroid receptor-positive cells. Dev. Biol. 277: 443-456.

Dauvois, S., Danielian, PS., White, R., Parker, MG. 1992. Antiestrogen ICI 164,384 reduces cellular estrogen receptor content by increasing its turnover. Proc Natl Acad Sci U S A. 89: 4037-4041.

Dean, M., Fojo, T., Bates, S. 2005. Tumor stem cells and drug resistance. Nat. Rev. Cancer 5 (4): 275-284.

Deng, H., Huang, X., Fan, J., Wang, LB., XIia, Q., Yang, XP., Wang, ZY., Liu, LJ. 2010. A variant of estrogen receptor- $\alpha$, ER- $\alpha 36$ is expressed in human gastric cancer and is highly correlated with lymph node metastasis. Oncology Reports 24: 171-176.

Deng, H., Zhang, X.T., Wang, M. L., Zheng, H. Y., Liu, L. J., Wang, Z. Y. 2014. ER-alpha36mediated rapid estrogen signaling positively regulates ER-positive breast cancer stem/progenitor Cells.” PLos ONE. e88034. 
Deng, H., Yin, L., Zhang, XT., Liu, LJ., Wang, ML., Wang, ZY. 2014. ER-alpha variant ERalpha 36 mediates antiestrogen resistance in ER-positive breast cancer stem/progenitor cells. J Steroid Biochem. Mol. Biol.

Deroo, BJ., Buensuceso, AV. 2010. Minireview: Estrogen receptor-beta: mechanistic insights from recent studies. Mol. Endocrinol. 24: 1703-1714.

Diaz-Chico, BN., Ogasawara, Y., Chamness, GC., Salman, M., McGuire, WL. 1988. A 46-kDa antigen associated with estrogen receptor in human breast cancer. J Steroid Biochem. 30: 315320.

Diehn, M., Clarke, MF. 2006. Cancer stem cells and radiotherapy: new insights into tumor radioresistance. J. Natl. Cancer Inst. 98 (24): 1755-1757.

Dontu, G., Abdallah, WM., Foley, JM., Jackson, KW., Clarke, MF., Kawamura, MJ., Wicha MS. 2003. In vitro propagation and transcriptional profiling of human mammary stem/progenitor cells. Genes Dev. 17: 1253-1270.

Dontu, G., El-Ashry, D., Wicha, MS. 2004. Breast cancer, stem/progenitor cells and the estrogen receptor. Trends Endocrinol. Metab. 15: 193-197.

Driggers, PH., Segars, JH. 2002. Estrogen action and cytoplasmic signaling pathways. Part II: the role of growth factors and phosphorylation in estrogen signaling. Trends Endocrinol. Metab. 13: 422-427.

Dufy, B., Vincent, JD., Fleury, H., Du Pasquier, P., Gourdji, D., Tixier-Vidal, A. 1979. Membrane effects of thyrotropin-releasing hormone and estrogen shown by intracellular recording from pituitary cells. Science. 204: 509-511.

Endoh, H., Sasaki, H., Maruyama, K., Takeyama, K., Waga, I., Shimizu, T., Kato, S., Kawashima, H. 1997. Rapid activation of MAP kinase by estrogen in the bone cell line. Biochem. Biophys. Res. Commun. 235: 99-102.

Evans, MJ., Eckert, A., Lai, K., Adelman, SJ., Harnish, DC. 2001. Reciprocal antagonism between estrogen receptor and NF-kappaB activity in vivo. Circ. Res. 89: 823-830.

Fawell, SE., White, R., Hoare, S., Sydenham, M., Page, M., Parker, MG. 1990. Inhibition of estrogen receptor-DNA binding by the "pure" antiestrogen ICI 164,384 appears to be mediated by impaired receptor dimerization. Proc Natl Acad Sci U S A. 87:6883-6887.

Feigelson, HS., Henderson, BE. 1996. Estrogens and breast cancer. Carcinogenesis. 17: 22792284.

Filardo, EJ., Quinn, JA., Bland, KI., Frackelton, AR. Jr. 2000. Estrogen-induced activation of Erk-1 and Erk-2 requires the G protein-coupled receptor homolog, GPR30, and occurs via transactivation of the epidermal growth factor receptor through release of HB-EGF. Mol. Endocrinol. 14:1649-1660.

Filardo, E., Quinn, J., Pang, Y., Graeber, C., Shaw, S., Dong, J., Thomas, P. 2007. Activation of the novel estrogen receptor $G$ protein-coupled receptor 30 (GPR30) at the plasma membrane. Endocrinology 148: 3236-3245.

Fillmore, CM., Gupta, PB., Rudnick, JA., Caballero, S., Keller, PJ., Lander, ES., Kuperwasser, C. Estrogen expands breast cancer stem-like cells through paracrine FGF/Tbx3 signaling. Proc Natl Acad Sci U S A. 2010; 107: 21737-42.

Flouriot, G, Brand, H., Denger, S., Metivier, R., Kos, M., Reid, G., Sonntag-Buck, V., Gannon, F. 2000. Identification of a new isoform of the human estrogen receptor-alpha (hER-alpha) that is encoded by distinct transcripts and that is able to repress hER-alpha activation function 1 . EMBO J. 19: 4688-4700. 
Fox, EM., Bernaciak, TM., Wen, J., Weaver, AM., Shupnik, MA., Silva, CM. 2008. Signal transducer and activator of transcription $5 \mathrm{~b}, \mathrm{c}-\mathrm{Src}$, and epidermal growth factor receptor signaling play integral roles in estrogen-stimulated proliferation of estrogen receptor-positive breast cancer cells. Mol. Endocrinol. 22: 1781-1796.

Galluzzo, P., Caiazza, F., Moreno, S., Marino, M. 2007. Role of ER-beta palmitoylation in the inhibition of human colon cancer cell proliferation. Endocr. Relat. Cancer. 14: 153-167.

Gao, F., Ma, X., Ostmann, AB., Das, SK. 2011. GPR30 activation opposes estrogen estrogen dependent uterine growth via inhibition of stromal ERK1/2 and estrogen receptor alpha (ERalpha) phosphorylation signals. Endocrinology 152: 1434-1447.

Garcia, M., Derocq, D., Freiss, G., Rochefort, H. 1992. Activation of estrogen receptor transfected into a receptor-negative breast cancer cell line decreases the metastatic and invasive potential of the cells. Proc Natl Acad Sci. USA. 89 (23): 11538-11542.

Ginestier, C., Hur, MH., Charafe-Jauffret, E., Monville, F., Dutcher, J., Brown, M., Jacquemier, J., Viens, P., Kleer, CG., Liu, S., Schott, A., Hayes, D., Birnbaum, D., Wicha, MS., Dontu, G. 2007. ALDH1 is a marker of normal and malignant human mammary stem cells and a predictor of poor clinical outcome. Cell Stem Cell 5: 555-567.

Green, S., Walter, P., Kumar, V., Krust, A., Bornert, JM., Argos, P., Chambon, P. 1986. Human oestrogen receptor cDNA: sequence, expression and homology to v-erb-A. Nature. 320: 134139.

Greene, GL., Gilna, P., Waterfield, M., Baker, A, Hort, Y., Shine, J. 1986. Sequence and expression of human estrogen receptor complementary DNA. Science. 231: 1150-1154.

Gu, Q., Korach, KS., Moss, RL. 1999. Rapid action of 17beta-estradiol on kainate-induced currents in hippocampal neurons lacking intracellular estrogen receptors. Endocrinology. 140: 660-666.

Gupta, PB., Proia, D., Cingoz, O., Weremowicz, J., Naber, SP., Weinberg, RA., Kuperwasser, C. 2007. Systemic stromal effects of estrogen promote the growth of estrogen receptor-negative cancers. Cancer Res. 67: 2062-2071.

Hammes, SR., Levin, ER. 2007. Extranuclear steroid receptors: nature and actions. Endocr. Rev. 28: 726-741.

Han, JS, Crowe, DL. 2009. Tumor initiating cancer stem cells from human breast cancer cell lines. Int J Oncol 34:1449-1453.

Harnish, DC., Scicchitano, MS., Adelman, SJ., Lyttle, CR., Karathanasis, SK. 2000. The role of CBP in estrogen receptor cross-talk with nuclear factor-kappaB in HepG2 cells. Endocrinology. 141: 3403-3411.

Harris, HA. 2007. Estrogen receptor-beta: recent lessons from in vivo studies Mol. Endocrinol. 21: 1-13.

Hartman, J., Lindberg, K., Morani, A., Inzunza, J., Strom, A., Gustafsson, JA. 2006. Estrogen receptor beta inhibits angiogenesis and growth of T47D breast cancer xenografts. Cancer Res. 66: 11207-11213.

Howell, A., Osborne, CK., Morris, C., Wakeling, AE. 2000. ICI 182,780 (Faslodex): development of a novel, "pure" antiestrogen. Cancer. 89: 817-825.

Jensen, EV., Cheng, G., Palmieri, C., Saji, S., Makela, S., Van Noorden, S., Wahlstrom, T., Warner, M., Coombes, RC \& Gustafsson, JA. 2001. Estrogen receptors and proliferation markers in primary and recurrent breast cancer. Proc Natl Acad Sci USA. 98: 15197-15202. 
Jiang, H., Teng, R., Wang, Q., Zhang, XT., Wang, H., Wang, ZY., Cao, J., Teng, LS. 2008. Transcriptional analysis of estrogen receptor alpha variant mRNAs in colorectal cancers and their matched normal colorectal tissues. J Steroid Biochem. Mol. Biol. 112: 20-24.

Jiang, SY., Jordan, VC. 1992. Growth regulation of estrogen receptor-negative breast cancer cells transfected with complementary DNAs for estrogen receptor. J Natl. Cancer Inst. 84:580591.

Jordan, NJ., Gee, JM., Barrow, D., Wakeling, AE., Nicholson, RI. 2004. Increased constitutive activity of PKB/Akt in tamoxifen resistant breast cancer MCF-7 cells. Breast Cancer Res. Treat. 87: 167-180.

Jozan, S., Julia, AM., Carretie, A., Eche, N., Maisongrosse, V., Fouet, B., Marques, B., David, JF. 1991. 65 and $47 \mathrm{kDa}$ forms of estrogen receptor in human breast cancer: relation with estrogen responsiveness. Breast Cancer Res. Treat. 19: 103-109.

Kang, LG., Wang, ZY. 2010. Breast cancer cell growth inhibition by phenethyl isothiocyanate is associated with down-regulation of oestrogen receptor-alpha36. J. Cell Mol. Med. 14: 14851493.

Kang, LG., Zhang, XT., Xie, Y., Tu, YP., Wang, D., Liu, ZM., Wang, ZY. 2010. Involvement of estrogen receptor variant ER-alpha36, not GPR30, in nongenomic estrogen signaling. Mol. Endocrinol. 24: 709-721.

Kang, L., Guo, YM., Zhang, XT., Wang, ZY. 2011. A positive cross-regulation of HER2 and ER-alpha36 controls ALDH1 positive breast cancer cells. J Steroid Biochem. Mol. Biol. 127: 262-268.

Kato, S., Endoh, H., Masuhiro, Y., Kitamoto, T., Uchiyama, S., Sasaki, H., Masushige, S., Gotoh, Y., Nishida, E., Kawashima, H., Metzger, D., Chambon, P. 1995. Activation of the estrogen receptor through phosphorylation by mitogen-activated protein kinase. Science. 270: 1491-1494.

Katzenellenbogen, BS., Katzenellenbogen, JA. 2000. Estrogen receptor transcription and transactivation: Estrogen receptor alpha and estrogen receptor beta: regulation by selective estrogen receptor modulators and importance in breast cancer. Breast Cancer Res. 2:335-344.

Kelly, MJ., Levin, ER. 2001. Rapid actions of plasma membrane estrogen receptors. Trends Endocrinol. Metab. 12: 152-156.

Kelly, MJ., Moss, RL., Dudley, CA. 1976. Differential sensitivity of preoptic-septal neurons to microelectrophoresed estrogen during the estrous cycle. Brain Res. 114: 152-157.

Kelly, MJ., Moss, RL., Dudley, CA., Fawcett, CP. 1977. The specificity of the response of preoptic-septal area neurons to estrogen: 17alpha-estradiol versus 17beta-estradiol and the response of extrahypothalamic neurons. Exp. Brain Res. 30: 43-52.

Khan, SA., Rogers, MA., Obando, JA., Tamsen, A. 1994. Estrogen receptor expression of benign breast epithelium and its association with breast cancer. Cancer Res. 54: 993-997.

Kim, KH., Bender, JR. 2005. Rapid, estrogen receptor-mediated signaling: why is the endothelium so special? Sci. STKE. 2005: pe28.

Kim, R., Kaneko, M., Arihiro, K., Emi, M., Tanabe, K., Murakami, S., Osaki, A., Inai, K. 2006. Extranuclear expression of hormone receptors in primary breast cancer. Ann Oncol 17: 12131220.

Klinge, CM. (2001). Estrogen receptor interaction with estrogen response elements. Nucleic Acids Res. 29:2905-2919.

Klinge, CM., Riggs, KA., Wickramasinghe, NS., Emberts, CG., McConda, DB., Barry, PN., Magnusen, JE. 2010. Estrogen receptor alpha 46 is reduced in tamoxifen resistant breast cancer 
cells and re-expression inhibits cell proliferation and estrogen receptor alpha 66-regulated target gene transcription. Mol. Cell Endocrinol. 323:268-276.

Kong, EH., Pike, AC., Hubbard, RE. 2003. Structure and mechanism of the oestrogen receptor. Biochem. Soc. Trans. 31: 56-59.

Korkaya, H., Paulson, A., Iovino, F., Wicha, MS. 2008. HER2 regulates the mammary stem/progenitor cell population driving tumorigenesis and invasion. Oncogene 27: 6120-6130.

Korkaya, H., Paulson, A., Charfe-Jauffret, E., Ginestier, C., Brown, M., Dutcher, J., Clouthier,

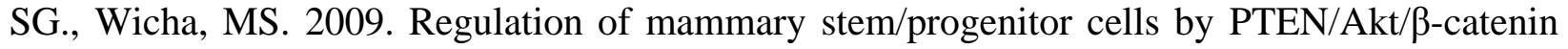
signaling. PLoS Biology 7: e1000121.

Kuiper, GG., Enmark, E., Pelto-Huikko, M., Nilsson, S., Gustafsson, J.A. 1996. Cloning of a novelreceptor expressed in rat prostate and ovary. Proc. Natl. Acad. Sci. USA. 93: 5925-5930.

Kushner, PJ., Hort, E., Shine, J., Baxter, JD., Greene, GL. 1990. Construction of cell lines that express high levels of the human estrogen receptor and are killed by estrogens. Mol. Endocrinol. 4: 1465-1473.

Kushner, PJ., Agard, DA., Greene, GL., Scanlan, TS., Shiau, AK., Uht, RM., Webb, P. 2000. Estrogen receptor pathways to AP-1. J. Steroid Biochem. Mol. Biol. 74: 311-317.

Lazennec, G., Bresson, D., Lucas, A., Chauveau, C., Vignon, F. 2001. ER beta inhibits proliferation and invasion of breast cancer cells. Endocrinology. 142:4120-4130.

Lee, LM., Cao, J., Deng, H., Chen, P., Gatalica, Z., Wang, ZY. 2008. ER-alpha36, a novel variant of ER-alpha, is expressed in ER-positive and -negative human breast carcinomas. Anticancer Res. 28:479-483.

Levin, ER. 2002. Cellular function of plasma membrane estrogen receptors. Steroids. 67: 471475.

Levin, ER. 2003. Bidirectional signaling between the estrogen receptor and the epidermal growth factor receptor. Mol. Endocrinol. 17: 309-317.

Levin, ER. 2009. Plasma membrane estrogen receptors. Trends Endocrinol Metab. 20: 477-482.

Li, L., Haynes, MP., Bender, JR. 2003. Plasma membrane localization and function of the estrogen receptor alpha variant (ER46) in human endothelial cells. Proc Natl Acad Sci U S A. 100: 4807-4812.

Lin, SL., Yan, LY., Liang, XW., Wang, ZB., Wang, ZY., Qiao, J., Schatten, H., Sun, QY. 2009. A novel variant of ER-alpha, ER-alpha 36 mediates testosterone-stimulated ERK and Akt activation in endometrial cancer Hec1A cells. Reprod. Biol. Endocrinol. 7: 102.

Lin, SL., Yan, LY., Zhang, XT., Yuan, J., Li, M., Qiao, J., Wang, ZY., Sun, QY. 2010. ER alpha 36, a variant of ER-alpha, promotes tamoxifen agonist action in endometrial cancer cells via the MAPK/ERK and PI3K/Akt pathways. PLoS One. 5: e9013.

Lindsey, SH., Yamaleyva, LM., Brosnihan, KB., Gallapher, PE., Chappell, MC. 2011. Estrogen receptor GPR30 reduces oxidative stress and proteinuria in the salt-sensitive female mRen2Lewis rat. Hypertension. 58: 665-671.

Lobenhofer, EK., Huper, G., Iglehart, JD., Marks, JR. 2000. Inhibition of mitogen activated protein kinase and phosphatidylinositol 3-kinase activity in MCF-7 cells prevents estrogeninduced mitogenesis. Cell Growth Differ. 11: 99-110.

Longo, M., Brama, M., Marino, M., Bernardini, S., Korach, KS., Wetsel, WC., Scandurra, R., Faraggiana, T., Spera, G., Baron, R., Teti, A., Migliaccio, S. 2004. Interaction of estrogen receptor alpha with protein kinase $\mathrm{C}$ alpha and $\mathrm{c}-\mathrm{Src}$ in osteoblasts during differentiation. Bone. 34: 100-111. 
Lu, Q., Pallas, DC., Surks, HK., Baur, WE., Mendelsohn, ME., Karas, RH. 2004. Striatin assembles a membrane signaling complex necessary for rapid, nongenomic activation of endothelial NO synthase by estrogen receptor alpha. Proc Natl Acad Sci U S A 101: 1712617131.

Mahfoudi, A., Roulet, E., Dauvois, S., Parker, MG., Wahli, W. 1995. Specific mutations in the estrogen receptor change the properties of antiestrogens to full agonists. Proc Natl Acad Sci U S A. 92: 4206-4210.

Mallepell, S., Krust, A., Chambon, P., Brisken, C. 2006. Paracrine signaling through the epithelial estrogen receptor alpha is required for proliferation and morphogenesis in the mammary gland. Proc Natl Acad Sci U S A. 103: 2196-201.

Maret, A., Clamens, S., Delrieu, I., Elhage, R., Arnal, JF., Bayard, F. 1999. Expression of the interleukin- 6 gene is constitutive and not regulated by estrogen in rat vascular smooth muscle cells in culture. Endocrinology. 140: 2876-2882.

Margeat, E., Bourdoncle, A., Margueron, R., Poujol, N., Cavailles, V., Royer, C. 2003. Ligands differentially modulate the protein interactions of the human estrogen receptors alpha and beta. $\mathrm{J}$ Mol. Biol. 326:77-92.

Marino, M., Galluzzo, P., Ascenzi, P. 2006. Estrogen Signaling multiple pathways to impact gene transcription. Curr Genomics. 7: 497-508.

Marino, M., Ascenzi, P. 2008. Membrane association of estrogen receptor alpha and beta influences 17beta-estradiol-mediated cancer cell proliferation. Steroids. 73: 853-858.

Marquez, DC. Pietras, RJ. 2001. Membrane-associated binding sites for estrogen contribute to growth regulation of human breast cancer cells. Oncogene. 20:5420-5430.

McDonnell, DP., Norris, JD. 2002. Connections and regulation of the human estrogen receptor. Science. 296: 1642-1644.

McEwen, B. 2002. Estrogen actions throughout the brain. Recent Prog. Horm. Res. 57: 357-384.

McKay LI., Cidlowski, J.A. 1999. Molecular control of immune/inflammatory responses:

interactions between nuclear factor-kappa B and steroid receptor-signaling

pathways. Endocr Rev 20:435-459.

Mermelstein, PG., Becker, JB., Surmeier, DJ. 1996. Estradiol reduces calcium currents in rat neostriatal neurons via a membrane receptor. J Neurosci. 16: 595-604.

Metivier, R., Penot, G., Carmouche, RP., Hubner, MR., Reid, G., Denger, S., Manu, D., Brand, H., Kos, M., Benes, V., Gannon, F. 2004. Transcriptional complexes engaged by apo-estrogen receptor-alpha isoforms have divergent outcomes. EMBO J. 23: 3653-3666.

Miceli, V., Cocciadiferro, L., Fregapane, M., Zarcone, M., Montalto, G., Polito, LM., Agostara, B., Granata, OM., Carruba, G. 2011. Expression of wild-type and variant estrogen receptor alpha in liver carcinogenesis and tumor progression. OMICS. 15: 313-317.

Migliaccio, A., Castoria, G., Di Domenico, M., Ciociola, A., Lombardi, M., De Falco, A., Nanayakkara, M., Bottero, D., De Stasio, R., Varricchio, L., Auricchio, F. 2006. Crosstalk between EGFR and extranuclear steroid receptors. Ann N Y Acad Sci 1089: 194-200.

Migliaccio, A., Di Domenico, M., Castoria, G., de Falco, A., Bontempo, P., Nola, E., Auricchio, F. 1996. Tyrosine kinase/p21ras/MAP-kinase pathway activation byestradiol-receptor complex in MCF-7 cells. EMBO J 15: 1292-1300.

Migliaccio, A., Castoria, G., Di Domenico, M., de Falco, A., Bilancio, A., Lombardi, M., Bottero, D., Varricchio, L., Nanayakkara, M., Rotondi, A. Auricchio, F. 2002. Sex steroid hormones act as growth factors. J Steroid Biochem Mol Biol. 83: 31-35. 
Moriarty, K., Kim, KH., Bender, JR. 2006. Minireview: estrogen receptor-mediated rapid signaling. Endocrinology. 147: 5557-5563.

Morimoto, K., Kim, SJ., Tanei, T., Shimazu, K., Tanji, Y., Taguchi, T., Tamaki, Y., Noguchi, S. 2009. Stem cell marker aldehyde dehydrogenase 1-positive breast cancers are characterized by negative estrogen receptor, positive human epidermal growth factor receptor type 2, and high Ki67 expression. Cancer Sci. 100: 1062-1068.

Morley, P., Whitfield, JF., Vanderhyden, BC., Tsang, BK., Schwartz, JL. 1992. A new, nongenomic estrogen action: the rapid release of intracellular calcium. Endocrinology. 131: 1305-1312.

Nethrapalli, IS., Tinnikov, AA., Krishnan, V., Lei, CD., Toran-Allerand, CD. (2005). Estrogen activates mitogen-activated protein kinase in native, nontransfected $\mathrm{CHO}-\mathrm{K} 1, \mathrm{COS}-7$, and RAT2 fibroblast cell lines. Endocrinology. 146: 56-63.

Nicholson, RI., Gee, JM., Manning, DL., Wakeling, AE., Montano, MM., Katzenellenbogen, BS. 1995. Responses to pure antiestrogens (ICI 164384, ICI 182780) in estrogen sensitive and resistant experimental and clinical breast cancer. Ann. N Y Acad. Sci. 761: 148-163.

Nilsson, S., Makela, S., Treuter, E., Tujague, M., Thomsen, J., Andersson, G., Enmark, E., Pettersson, K., Warner, M. Gustafsson, JA. 2001. Mechanisms of estrogen action. Physiol. Rev. 81:1535-1565.

Nissen-Meyer, R. 1964. "Prophylactic" ovariectomy and ovarian irradiation in breast cancer. Acta. Unio. Int. Contra. Cancrum. 20: 527-530.

Normanno, N., Di Maio, M., De Maio, E., De Luca, A., Matteis, Ad., Giordano, A., Perrone, F. 2005. Mechanisms of endocrine resistance and novel therapeutic strategies in breast cancer. Endocrine-Related Cancer 12: 721-747.

O’Brien, CS., Howell, SJ., Farnie, G., R. B. Clarke, RB. 2009. Resistance to endocrine therapy: are breast cancer stem cells culprits. J. Mammary Gland Biol Neoplasia 14 (1): 45-54.

Ogawa, S., Inoue, S., Watanabe, T., Orimo, A., Hosoi, T., Ouchi, Y., Muramatsu, M. 1998. Molecular cloning and characterization of human estrogen receptor- $\beta$ cx: a potential inhibitor of estrogen action in human. Nucleic Acids Research 26(15): 3505-12.

Ohshiro, K., Schwartz, AM., Levine, PH., Kumar R. 2012. Alternate estrogen receptors promote invasion of inflammatory breast cancer cells via non-genomic signaling. PLoS One 7: e30725.

Oliveira, LR., Jeffrey, SS., Ribeiro-Silva, A. 2010. Stem cells in human breast cancer. Histol. Histopathol. 25: 371-385.

Osborne, CK., Yochmowitz, MG., Knight, WA., 3rd. McGuire, WL. 1980. The value of estrogen and progesterone receptors in the treatment of breast cancer. Cancer. 46: 2884-2888.

Otto, C, Fuchs, I., Kauselmann, G., Kern, H., Zevnik, B., Andreasen, P., Schwarz, G., Altmann, H., Klewer, M., Schoor M., Vonk, R., Fritzemeier, KH. 2009. GPR30 does not mediate estrogenic responses in reproductive organs in mice. Biol. Reprod. 80: 34-41.

Otto, C., Rohde-Schulz, B, Schwarz, G., Fuchs, I., Klewer, M., Brittain, D., Langer, G., Bader, B., Prelle, K., Nubbemeyer, R., Fritzemeier, KH. 2008. G protein-coupled receptor 30 localizes to the endoplasmic reticulum and is not activated by estradiol. Endocrinology. 149: 4846-4856.

Paruthiyil, S., Parmar, H., Kerekatte, V., Cunha, GR., Firestone, GL. Leitman, DC. 2004. Estrogen receptor beta inhibits human breast cancer cell proliferation and tumor formation by causing a G2 cell cycle arrest. Cancer Res. 64: 423-428.

Pearce, ST., Liu, H., Jordan, VC. 2003. Modulation of estrogen receptor alpha function and stability by tamoxifen and a critical amino acid (Asp-538) in helix 12. J Biol. Chem. 278: 76307638 . 
Pedram, A., Razandi, M., Levin, ER. 2006. Nature of functional estrogen receptors at the plasma membrane. Mol. Endocrinol. 20: 1996-2009.

Penot, G., Le Peron, C., Merot, Y., Grimaud-Fanouillere, E., Ferriere, F., Boujrad, N., Kah, O., Saligaut, C., Ducouret, B., Metivier, R. Flouriot, G. 2005. The human estrogen receptor-alpha isoform hERalpha46 antagonizes the proliferative influence of hERalpha66 in MCF7 breast cancer cells. Endocrinology. 146: 5474-5484.

Pietras, RJ., Marquez, DC., Chen, HW., Tsai, E., Weinberg, O., Fishbein, M. 2005. Estrogen and growth factor receptor interactions in human breast and non-small cell lung cancer cells. Steroids. 70: 372-381.

Pietras, RJ. Szego, CM. 1975. Endometrial cell calcium and oestrogen action. Nature. 253: 357359.

Paruthiyil, S., Parmar, H., Kerekatte, V., Cunha, GR., Firestone, GL., Leitman, DC. 2004. Estrogen recptor beta inhibits human breast cancer cell proliferation and tumor formation by causing a G2 cell cycle arrest. Cancer Res. 64: 423-428.

Pelekanou, V., Notas, G., Kampa, M. Tsentelierou, E., Radojicic, J., Leclercq, G., Castanas, E., Stathopoulos, EN. 2012. ERalpha36, a new variant of the ERalpha is expressed in triple negative breast carcinomas and has a specific transcriptomic signature in breast cancer cell lines. Steroids. 77(10):928-34

Pietras, RJ., Szego, CM. 1977. Specific binding sites for oestrogen at the outer surfaces of isolated endometrial cells. Nature. 265: 69-72.

Pilat, MJ., Christman, JK., Brooks, SC. 1996. Characterization of the estrogen receptor transfected MCF10A breast cell line 139B6. Breast Cancer Res. Treat. 37: 253-266.

Piva, M., Domenici, G., Iriondo, O., Rábano, M., Simões, BM., Comaills, V., Barredo, I., LópezRuiz, JA., Zabalza, I., Kypta, R., Vivanco, Md. 2013. Sox2 promotes tamoxifen resistance in breast cancer cells. EMBO Mol Med. 5: 1-14.

Prall, OW., Rogan, EM., Sutherland, RL. 1998. Estrogen regulation of cell cycle progression in breast cancer cells. J Steroid Biochem. Mol. Biol. 65: 169-174.

Prossnitz ER., Barton, M. 2011. The G protein-coupled estrogen receptor GPER in health and disease. Nat Rev Endocrinol. 7: 715-726.

Rao, BR. 1998. Isolation and characterization of an estrogen binding protein which may integrate the plethora of estrogenic actions in non-reproductive organs. J Steroid Biochem, Mol Biol. 65: 3-41.

Razandi, M., Pedram, A., Greene GL Levin, ER. 1999. Cell membrane and nuclear estrogen receptors (ERs) originate from a single transcript: studies of ER-alpha and ER-beta expressed in Chinese hamster ovary cells. Mol Endocrinol. 13: 307-319.

Razandi, M., Pedram, A., Park, ST., Levin, ER. 2003. Proximal events in signaling by plasma membrane estrogen receptors. J. Biol. Chem. 278 (4): 2701-2712.

Rebbeck, TR., Levin, AM., Eisen, A., Snyder, C., Watson, P., Cannon-Albright, L., Isaacs, C., Olopade, O., Garber, JE., Godwin, AK., Daly, MB., Narod, SA., Neuhausen, SL., Lynch, HT Weber, BL. 1999. Breast cancer risk after bilateral prophylactic oophorectomy in BRCA1 mutation carriers. J Natl. Cancer Inst. 91: 1475-1479.

Revankar, CM., Cimino, DF., Sklar, LA., Arterburn, JB., Prossnitz, ER. 2005. A transmembrane intracellular estrogen receptor mediates rapid cell signaling. Science. 307: 1625-1630.

Ring, A., Dowsett, M. 2004. Mechanisms of tamoxifen resistance. Endocr. Relat. Cancer. 11: 643-658. 
Robertson, JF. 1996. Oestrogen receptor: a stable phenotype in breast cancer. Br. J Cancer. 73: 5-12.

Rochefort, H. 1995. Oestrogen- and anti-oestrogen-regulated genes in human breast cancer. Ciba. Found. Symp. 191: 254-265.

Roger, P., Daures, JP., Maudelonde, T., Pignodel, C., Gleizes, M., Chapelle, J., Marty-Double, C., Baldet, P., Mares, P., Laffargue, F., Rochefort, H. 2000. Dissociated overexpression of cathepsin D and estrogen receptor alpha in preinvasive mammary tumors. Hum. Pathol. 31: 593600.

Roger, P., Sahla, ME, Makela, S., Gustafsson, JA, Baldet, P., Rochefort, H. 2001. Decreased expression of estrogen receptor beta protein in proliferative preinvasive mammary tumors. Cancer Res. 61: 2537-2541.

Russell, KS., Haynes, MP., Sinha D., Clerisme, E., Bender, JR. 2000. Human vascular endothelial cells contain membrane binding sites for estradiol, which mediate rapid intracellular signaling. Proc Natl Acad Sci U S A. 97: 5930-5935.

Safe, S. 2001. Transcriptional activation of genes by 17 beta-estradiol through estrogen receptorSp1 interactions. Vitam. Horm. 62: 231-252.

Segars, JH., Driggers, PH. 2002. Estrogen action and cytoplasmic signaling cascades. Part I: membrane-associated signaling complexes. Trends Endocrinol. Metab. 13: 349-354.

Shang, YF., Brown, M. 2002. Molecular determinants for the tissue specificity of SERMs. Science. 295: 2465-2468.

Shang, YF., Hu, X., DiRenzo, J., Lazar, MA., Brown, M. 2000. Cofactor dynamics and sufficiency in estrogen receptor-regulated transcription. Cell. 103: 843-852.

Shi, .L, Dong, B., Li, Z., Lu, Y., Ouyang, T., Li, J., Wang, T., Fan, Z., Fan, T., Lin, B., Wang, ZY., Xie, YT. 2009. Expression of ER-\{alpha\}36, a novel variant of estrogen receptor \{alpha\}, and resistance to tamoxifen treatment in breast cancer. J Clin. Oncol. 27: 3423-3429.

Shoker, BS., Jarvis, C., Clarke, RB., Anderson, E., Hewlett, J., Davies, MP., Sibson, DR., Sloane, JP 1999a. Estrogen receptor-positive proliferating cells in the normal and precancerous breast. Am. J Pathol. 155: 1811-1815.

Shoker, BS., Jarvis, C., Sibson, DR., Walker, C., Sloane, JP. 1999b. Oestrogen receptor expression in the normal and pre-cancerous breast. J Pathol. 188: 237-244.

Shupnik, MA. 2004. Crosstalk between steroid receptors and the c-Src-receptor tyrosine kinase pathways: implications for cell proliferation. Oncogene. 23: 7979-7989.

Sleeman, KE., Kendrick, H., Robertson, D., Isacke, CM., Ashworth, A., Smalley, MJ. 2007 Dissociation of estrogen receptor expression and in vivo stem cell activity in the mammary gland. J. Cell Biology, 176: 19-26.

Song, RX., McPherson, RA., Adam, L., Bao, Y., Shupnik, MA., Kumar, R., Santen, RJ. 2002. Linkage of rapid estrogen action to MAPK activation by ERalpha-Shc association and Shc pathway activation. Mol. Endocrinol. 16: 116-127.

Song, RX., Zhang, Z., Chen, Y., Bao, Y., R. J. Santen, RJ. 2007. Estrogen signaling via a linear pathway involving insulin-like growth factor I receptor, matrix metalloproteinases, and epidermal growth factor receptor to activate mitogen-activated protein kinase in MCF-7 breast cancer cells. Endocrinology. 148 (8): 4091-4101.

Speir, E., Yu, ZX., Takeda, K., Ferrans, VJ., Cannon, RO, 3rd. 2000. Competition for p300 regulates transcription by estrogen receptors and nuclear factor-kappaB in human coronary smooth muscle cells. Circ. Res. 87: 1006-1011. 
Sun, L., Wang, J., Zhang, .L, Li, X., Shen, D. 2013. Expression of ER-a36, a novel variant of estrogen receptor in endometrial carcinoma and its clinical significance. Gynecol Obstet Invest; 75(1): 68-72.

Sylvia, VL., Walton, J., Lopez, D., Dean, DD., Boyan, BD., Schwartz, Z. (2001). 17 beta estradiol-BSA conjugates and 17 beta-estradiol regulate growth plate chondrocytes by common membrane associated mechanisms involving PKC dependent and independent signal transduction. J Cell Biochem. 81: 413-429.

Tesarik, J., Mendoza, C. 1997. Direct non-genomic effects of follicular steroids on maturing human oocytes: oestrogen versus androgen antagonism. Hum. Reprod. Update. 3: 95-100.

Tice, DA., Biscardi, JS., Nickles, AL., Parsons, SJ. 1999. Mechanism of biological synergy between cellular Src and epidermal growth factor receptor. Proc Natl Acad Sci U S A. 96: 14151420 .

Tong, JS., Zhang, QH., Wang, ZB., Li, S., Yang, CR., Fu, XQ., Hou, Y., Wang, ZY., Sheng, J., Sun, QY. 2010. ER-alpha36, a novel variant of ER-alpha, mediates estrogen stimulated proliferation of endometrial carcinoma cells via the PKCdelta/ERK pathway. PLoS One. 5: e15408.

Toran-Allerand, CD., Guan, X., MacLusky, NJ., Horvath, TL., Diano, S., Singh, M., Connolly, ES., Jr., Nethrapalli, IS., Tinnikov, A. 2002. ER-X: a novel, plasma membrane associated, putative estrogen receptor that is regulated during development and after ischemic brain injury. $\mathrm{J}$ Neurosci. 22: 8391-8401.

Toran-Allerand, CD. 2005. Estrogen and the brain beyond ER- $\alpha$, ER- $\beta$, and $17 \beta$-Estradiol. Ann. N. Y. Acad. Sci 1052: 136-144.

Touitou, I., Mathieu, M., Rochefort, H. 1990. Stable transfection of the estrogen receptor cDNA into Hela cells induces estrogen responsiveness of endogenous cathepsin D gene but not of cell growth. Biochem. Biophys. Res. Commun. 169: 109-115.

Tsai, EM., Wang, SC., Lee, JN., Hung, MC. 2001. Akt activation by estrogen in estrogen receptor-negative breast cancer cells. Cancer Res. 61: 8390-8392.

Tu, BB., Lin, SL., Yan, LY., Wang, Z-Y., Sun, QY., Qiao, J. 2011. ER- alpha 36, a novel variant of estrogen receptor alpha, is involved in EGFR-related carcinogenesis in endometrial cancer. Am J Obstet Gynecol. 205: 227: e1-6.

Tzukerman, MT., Esty, A., Santiso-Mere, D., Danielian, P., Parker, MG., Stein, RB., Pike, JW., McDonnell, DP. 1994. Human estrogen receptor transactivational capacity is determined by both cellular and promoter context and mediated by two functionally distinct intramolecular regions. Mol. Endocrinol. 8:21-30.

Vranic, S., Gatalica,, Z., Deng, H., Frkovic-Grazio, S., Lee, MJ., Olga Gurjeva, O., Wang, ZY. 2011. ER-alpha36, a novel isoform of ER- alpha 66, is commonly over-expressed in apocrine and adenoid cystic carcinomas of the breast. J. of Clinical Pathology. 64: 54-57.

Wade, CB., Robinson, S., Shapiro, RA., D. M. Dorsa, DM. 2001. Estrogen receptor (ER) alpha and ERbeta exhibit unique pharmacologic properties when coupled to activation of the mitogenactivated protein kinase pathway. Endocrinology. 142 (6): 2336-2342.

Wagner, EF., Nebreda, AR. 2009. Signal integration by JNK and p38 MAPK pathways in cancer development. Nat Rev Cancer 9: 537-549.

Wallacides, A., Chesnel, A., Ajj, H., Chillet, M., Flament, S., Dumond, H. 2012. Estrogens promote proliferation of the seminoma-like TCam-2 cell line through a GPER-dependent ERalpha36 induction. Mol Cell Endocrinol. 350: 61-71. 
Wang, J., Li, J., Fang, R., Xie, S., Wang, L., Xu, C. 2012. Expression of ERalpha36 in gastric cancer samples and their matched normal tissues. Oncol Lett. 3: 172-175.

Wang, ZY., Zhang, XT., Shen, P., Loggie, BW., Chang, Y., Deuel, TF. 2005. Identification, cloning, and expression of human estrogen receptor-alpha36, a novel variant of human estrogen receptor-alpha66. Biochem. Biophys. Res. Commun. 336: 1023-1027.

Wang, ZY., Zhang, XT., Shen, P., Loggie, BW., Chang, Y., Deuel, TF. 2006. A variant of estrogen receptor-\{alpha\}, hER-\{alpha\}36: transduction of estrogen- and antiestrogen-dependent membrane-initiated mitogenic signaling. Proc Natl Acad Sci U S A. 103: 9063-9068.

Warner, M., Saji, S., Gustafsson, JA. 2000. The normal and malignant mammary gland: a fresh look with ER-beta onboard. J Mammary Gland Biol. Neoplasia. 5: 289-294.

Watson, C., Norfleet, A., Pappas, T., Gametchu, B. 1999. Rapid actions of estrogens in GH3/B6 pituitary tumor cells via a plasma membrane version of estrogen receptor- alpha. Steroids. 64: 513.

Watters, JJ., Campbell, JS., Cunningham, MJ., Krebs, EG., Dorsa, DM. 1997. Rapid membrane effects of steroids in neuroblastoma cells: effects of estrogen on mitogen activated protein kinase signaling cascade and c-fos immediate early gene transcription. Endocrinology. 138: 4030-4033. Woodward, WA., Chen, MS., Behbod, F., Alfaro, MP., Buchholz, TA., Rosen, JM. 2007. WNT/beta-catenin mediates radiation resistance of mouse mammary progenitor cells. Proc. Natl. Acad. Sci. USA 104: 618-623.

Yamashita, H., Iwase, H., Toyama, T., Fujii, Y. 2003. Naturally occurring dominant-negative Stat5 suppresses transcriptional activity of estrogen receptors and induces apoptosis in T47D breast cancer cells. Oncogene. 22: 1638-1652.

Yin, L., Zhang, X. T., Bian X. W., Guo Y. M., Wang, Z. Y. 2014. Disruption of the ER-alpha36EGFR/HER2 positive regulatory loops restores tamoxifen sensitivity in tamoxifen Resistance breast cancer cells. PLos ONE. In Press.

Yu, LF., Ke, W., Wang, YL., Ding, W., Wang, B., Sui Huang, S., Chen, J., Wang, XT., Wang, ZY., Shen, P. 2014. Predictive and prognostic value of ER- alpha 36 expression in breast cancer patients treated with chemotherapy. Steroids 84: 11-16.

Zeps, N., Bentel, JM., Papadimitriou, JM., Dawkins, HJ. 1999. Murine progesterone receptor expression in proliferating mammary epithelial cells during normal pubertal development and adult estrous cycle; association with ER-alpha and ER-beta status. J Histochem. Cytochem. 47: 1323-1330.

Zhang, J., Li G., Li, Z., Yu, X., Zheng, Y., Jin, K., Wang, H., Gong, Y., Sun, X., Teng, X., Cao, J., Teng, L. 2012. Estrogen-independent effects of ER-alpha36 in ER-negative breast cancer. Steroids. 77: 666-673.

Zhang, XT., Kang, LG., Ding, L., Vranic, S., Gatalica, Z., Wang, ZY. 2011. A positive feedback loop of ER-alpha36/EGFR promotes malignant growth of ER-negative breast cancer cells. Oncogene. 30: 770-780.

Zhang, XT., Ding, L., Kang, LG., Wang, Z-Y. 2012. Estrogen receptor alpha 36 mediates mitogenic antiestrogen signaling in ER-negative breast cancer cells. PLos ONE. 7(1): e30174.

Zhang, X.T., Wang, Z-Y. 2013. Estrogen receptor- alpha variant, ER- alpha 36, is involved in tamoxifen resistance and estrogen hypersensitivity. Endocrinology. 154: 1990-1998

Zhang, XT., Deng, H., Wang, ZY. 2014. Estrogen activation of the mitogen-activated protein kinase is mediated by ER-alpha36 in ER-positive breast cancer cells. Journal of Steroid Biochemistry \& Molecular Biology. 143: 434-443. 
Zhao, L., O'Neill, K., Brinton, RD. 2006. Estrogenic agonist activity of ICI 182,780 (Faslodex) in hippocampal neurons: implications for basic science understanding of estrogen signaling and development of estrogen modulators with a dual therapeutic profile. J Pharmacol. Exp. Ther. 319: 1124-1132.

Zhao, L., O'Neill, K., Diaz Brinton, R. 2005. Selective estrogen receptor modulators (SERMs) for the brain: current status and remaining challenges for developing Neuro-SERMs. Brain Res. Rev. 49: 472-493.

Zheng, WH., Andersson, S., Cheng, G., Simpson, ER., Warner, M., Gustafsson, JA. 2003. Update on estrogen signaling. FEBS Lett. 546: 17-24.

Zou, Y., Ding, L., Coleman, M., Wang, ZY. 2009. Estrogen receptor-alpha (ER-alpha) suppresses expression of its variant ER-alpha 36. FEBS Lett. 583: 1368-1374. 


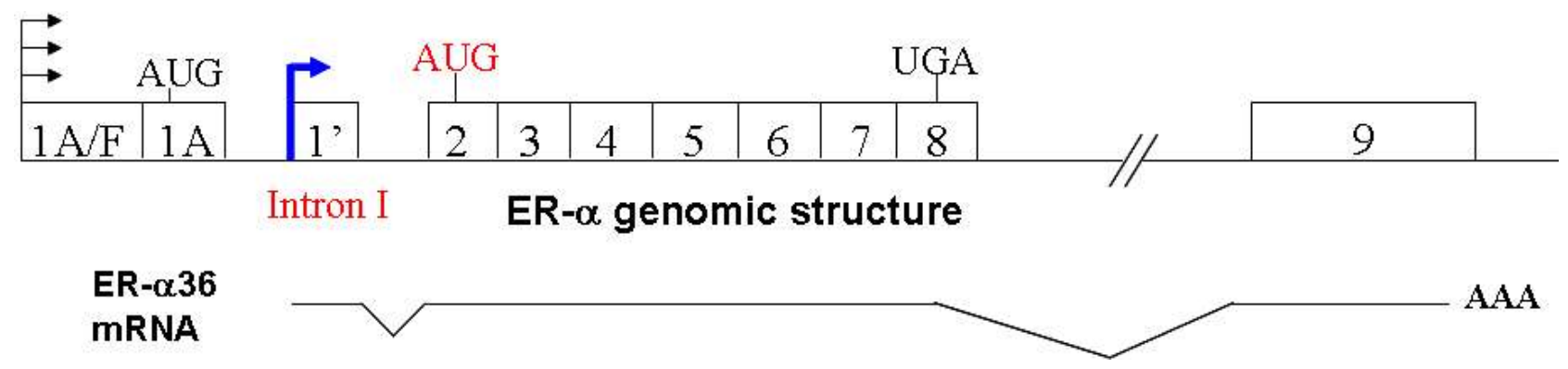

Figure 1. Genomic structure of the ER- $\alpha 36$ gene. The common exons between the ER- $\alpha 36$ and ER- $\alpha 66$ genes are shown as numbered boxes. The exon of ER- $\alpha 36$ from the intron 1 of ER- $\alpha 66$ gene was indicated as 1' and the extra exon of the ER- $\alpha 36$ gene that is beyond the 8 exons found in ER- $\alpha 66$ gene is numbered as 9. ER- $\alpha 36$ has a unique 27 amino acid domain at the Cterminus. Alternative splicing is indicated by a bended line. 


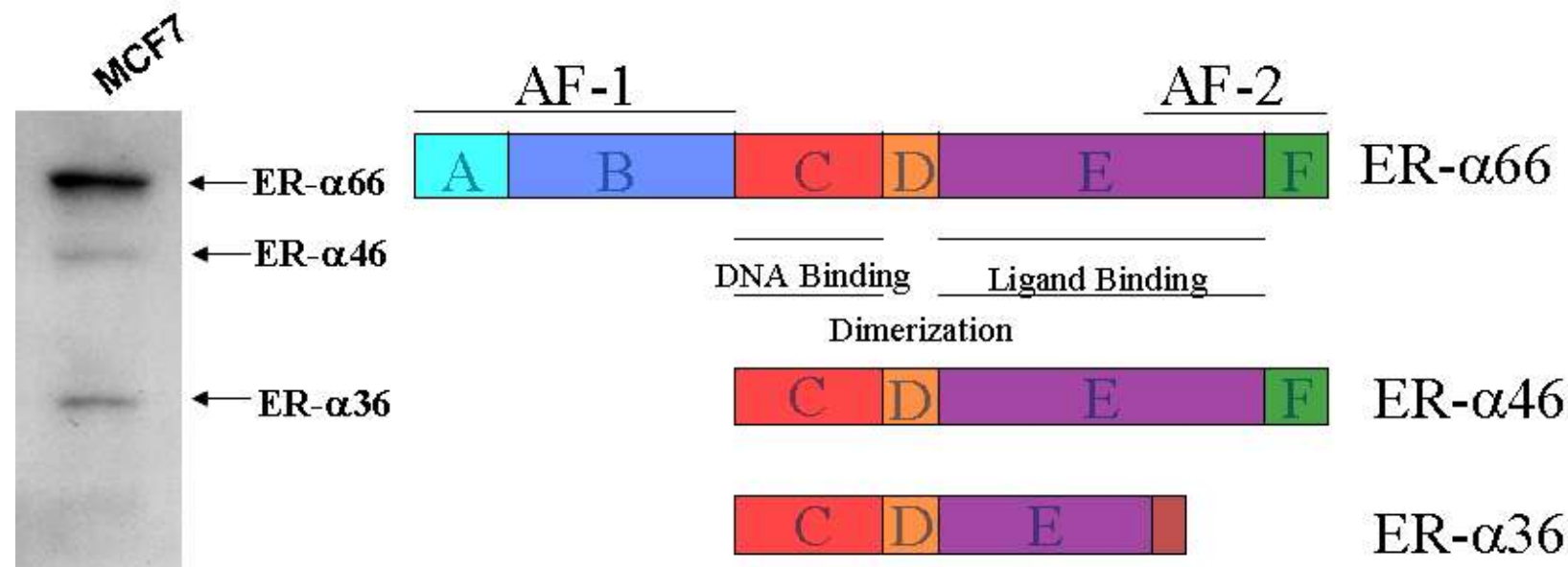

Figure 2. Protein structures of ER isoforms. The A/B domain contains the transcriptionalactivation function $\mathrm{AF}-1$; the $\mathrm{C}$ domain represents the DNA-binding-domain (DBD); D contains the nuclear localization signal (NLS), E domain corresponds to the ligand-binding domain (LBD) and the transcriptional-activation function AF-2. ER- $\alpha 36$ lacks AF-1 and AF-2. The last 27 amino acids of ER- $\alpha 36$ are indicated. Representative Western blot result of MCF7 cells with the $\mathrm{H} 226$ antibody that recognizes the hinge region (D) is also shown. 


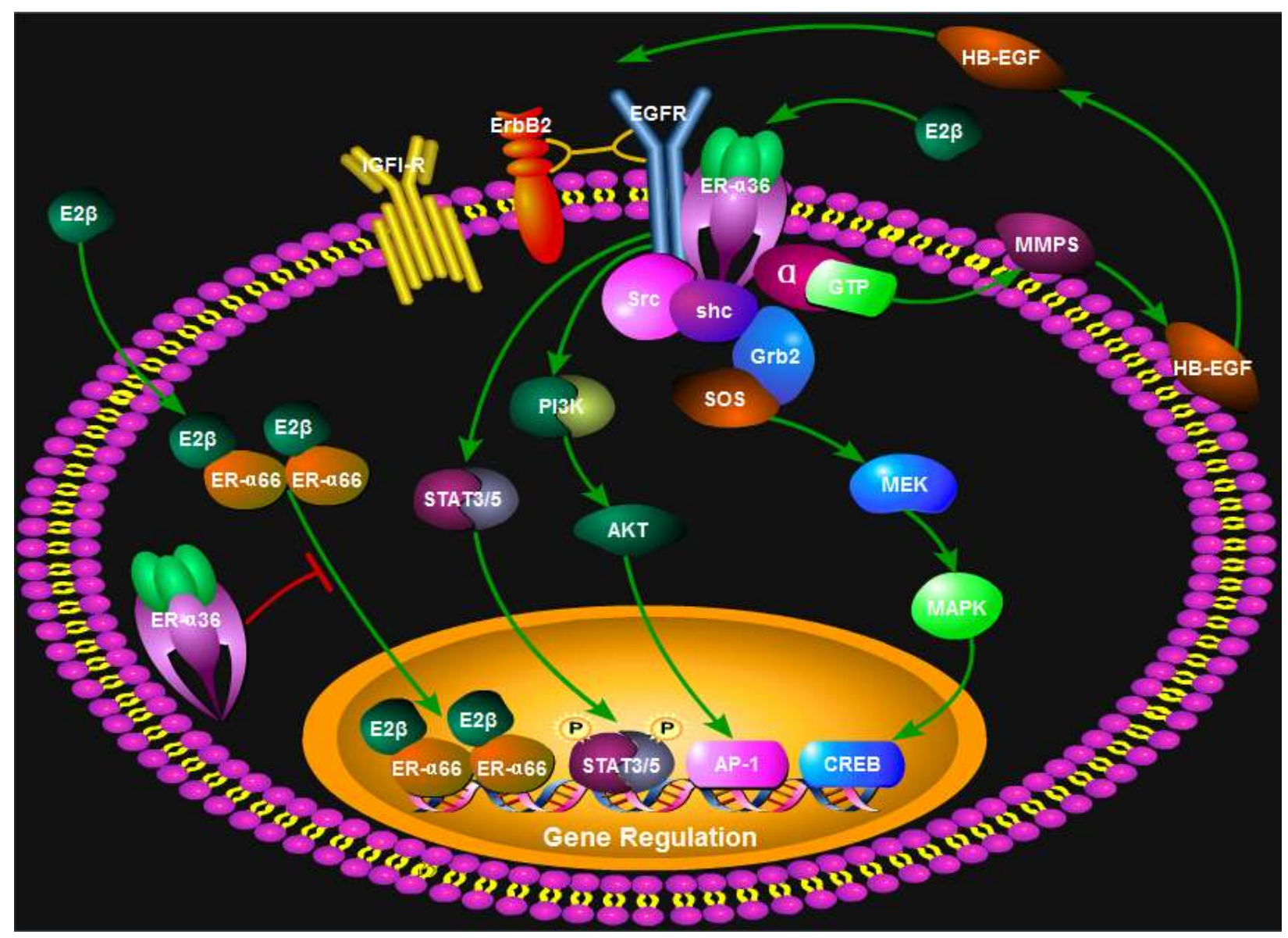

Fig. 3. The signaling pathways of ER- $\alpha 36-$ mediated rapid estrogen signaling. ER- $\alpha 36$ mediates E2-stimulated release of HB-EGF though the matrix metalloproteinases (MMP)-2 and -9 activated by the $G$ proteins via Src signaling. HB-EGF then activates EGFR and HER2, which also involve IGF-IR. ER- $\alpha 36$ then mediates rapid estrogen signaling via the signaling proteins such as c-Src and the adaptor proteins such as Shc leading to activation of the PI3K/AKT and MAPK/ERK signaling pathways as well as downstream transcription factors such as AP-1 and CREB. ER- $\alpha 36$-mediated rapid estrogen signaling may also involve direct activation of the STAT3/5 through the EGFR/Src. The physical interactions between ER- $\alpha 36$ and EGFR or HER2 are also indicated. The possible role of ER- $\alpha 36$ in inhibition of genomic estrogen signaling mediated by ER- $\alpha 66$ is also indicated. 